\title{
Ecotoxicological Assessment of Microplastics in Freshwater Sources-A Review
}

\author{
Martina Miloloža ${ }^{1}$, Dajana Kučić Grgić ${ }^{1, *}$, Tomislav Bolanča ${ }^{1}$, Šime Ukić ${ }^{1}$, Matija Cvetnić ${ }^{1}$, \\ Vesna Ocelić Bulatović ${ }^{2}$, Dionysios D. Dionysiou ${ }^{3}$ and Hrvoje Kušić ${ }^{1, *}$
}

1 Faculty of Chemical Engineering and Technology, University of Zagreb, 10000 Zagreb, Croatia; miloloza@fkit.hr (M.M.); tbolanca@fkit.hr (T.B.); sukic@fkit.hr (Š.U.); mcvetnic@fkit.hr (M.C.)

2 Faculty of Metallurgy, University of Zagreb, 44000 Sisak, Croatia; vocelicbu@simet.hr

3 Environmental Engineering and Science Program, University of Cincinnati, Cincinnati, OH 45221-0012, USA; dionysdd@ucmail.uc.edu

* Correspondence: dkucic@fkit.hr (D.K.G.); hkusic@fkit.hr (H.K.); Tel.: +385-1-4597-160 (H.K.); Fax: +385-1-4597-143 (H.K.)

check for

updates

Citation: Miloloža, M.; Kučić Grgić,

D.; Bolanča, T.; Ukić, Š.; Cvetnić, M.;

Ocelić Bulatović, V.; Dionysiou, D.D.;

Kušić, H. Ecotoxicological

Assessment of Microplastics in

Freshwater Sources-A Review.

Water 2021, 13, 56. https://doi.org/

10.3390/w13010056

Received: 26 November 2020

Accepted: 24 December 2020

Published: 30 December 2020

Publisher's Note: MDPI stays neutral with regard to jurisdictional clai$\mathrm{ms}$ in published maps and institutional affiliations.

Copyright: (C) 2020 by the authors. Licensee MDPI, Basel, Switzerland. This article is an open access article distributed under the terms and conditions of the Creative Commons Attribution (CC BY) license (https:// creativecommons.org/licenses/by/ $4.0 /)$.

\begin{abstract}
High living standards and a comfortable modern way of life are related to an increased usage of various plastic products, yielding eventually the generation of an increased amount of plastic debris in the environment. A special concern is on microplastics (MPs), recently classified as contaminants of emerging concern (CECs). This review focuses on MPs' adverse effects on the environment based on their bioactivity. Hence, the main topic covered is MPs' ecotoxicity on various aquatic (micro)organisms such as bacteria, algae, daphnids, and fish. The cumulative toxic effects caused by MPs and adsorbed organic/inorganic pollutants are presented and critically discussed. Since MPs' bioactivity, including ecotoxicity, is strongly influenced by their properties (e.g., types, size, shapes), the most common classification of MPs types present in freshwater are provided, along with their main characteristics. The review includes also the sources of MPs discharge in the environment and the currently available characterization methods for monitoring MPs, including identification and quantification, to obtain a broader insight into the complex problem caused by the presence of MPs in the environment.
\end{abstract}

Keywords: microplastics; freshwater; ecotoxicology; (micro)organisms

\section{Microplastics as an Emerging Environmental Problem}

The global production of plastic materials increased tremendously; from $~ 1.5$ million tons (MT) in 1950 up to 187 MT in 2000, then to 265 MT in 2010, while in 2018 production was 360 MT [1,2]. Reasons for such exponential increase rate are cost-effective production and wide applicability of plastic materials relying on their excellent properties: lightness, strength, and resistance/durability [3]. However, it should be noted that anthropogenic litter of plastic material in the environment ranges from $60-80 \%$ of the produced amount, which means that large quantities of plastic waste dramatically increased over the last decades as well [4].

Special attention has been recently given to tiny plastic particles $(<5 \mathrm{~mm})$ called microplastics (MPs) that have also been detected in the environment [5]. The boundary of $5 \mathrm{~mm}$ represents the upper limit for particles that can be readily ingested by organisms [3,6-8]. Although microplastics is a commonly used term, the more detailed classification includes: mesoplastics (1-5 mm), microplastics $(0.0001-1 \mathrm{~mm})$, and nanoplastics $(<0.1 \mu \mathrm{m})[9]$.

MPs discharge in the environment occurs through various transport media: sewage sludge, urban runoff and dust, industrial and municipal wastewater. Accordingly, MPs are detected in almost all environmental components/constituents: seas [10-13], freshwaters $[14,15]$, sediments $[12,13,16]$, soils $[17,18]$ and even atmosphere $[19,20]$. The major MPs 
sources identified are synthetic textiles (34\%), tire wear (29\%), city dust (24\%), road markings/dust $(7 \%)$, marine coatings $(4 \%)$, microbeads $(2 \%)$, and plastic pellets $(0.3 \%)[19,21]$. MPs distribution, abundance, and occurrence in the environment are affected by various factors: type of environment, MPs properties (type, density, size, and shape), climate regions (air turbulence, waves), industrialization, urbanization (proportional to MP's concentrations), waste management, development in general, and the living standard of gravitating society $[14,15]$. MPs are insoluble in water and have low susceptibility to degradation; therefore, they remain in the environment for long period [6]. MPs possess large bioaccumulation potential [17]. Studies showed that MPs exhibited harmful effects to organisms, particularly aquatic ones due to the direct contact. Hence, these may be reflected as behavioral effects, oxidative stress, neurotoxicity, genotoxicity, reproductive impairment, and hepatic damage $[9,22,23]$. MPs intake by humans is mostly through food and beverages, such as fish [17], mollusks [24], sugar [25], sea salt [26], beer [27], or even tap and bottled water $[7,28]$. Hence, it is not surprising that many countries recognize MPs as contaminants of emerging concern (CECs) with severe hazard potential [29,30].

Understanding MPs' behavior in the environment and related impact on abiotic and biotic qualities of ecosystems (including the possible impact on humans) is the basis for correct risk assessment. European Chemicals Agency (ECHA) considers that current information is insufficient to derive a robust predicted non-effective MPs concentration, i.e., a threshold value that could be used as proof that risks are adequately controlled. This means that any MPs release in the environment should be considered as risk [31]. Therefore, ECHA proposed the restriction of MPs usage in different professional, agricultural, industrial, and consumer products. The 1st restriction phase is planned for 2021 with a 5-year transition period; ECHA considered that is sufficient time for the industry to substitute MPs. The estimation is that the proposed restriction would yield a reduction of MPs emission of $\sim 400,000$ tones within the next 20 years [31]. Additional devastating fact is that developed world economies recycle $<30 \%$ of plastic-waste [32]. European Commission brought European Strategy for Plastics in a Circular Economy [33] presenting the vision for confronting MPs pollution, including better design of plastic products, a higher rate of plastic-waste recycling, and better quality recyclates-all boosting the recycled-plastics market.

This review summarizes the main properties of plastic materials that are mostly used and consequently, discharged into the environment. The knowledge of these properties is highly important due to the correlation with their overall environmental fate and behavior. The comparison of mostly common MP's characterization methods is also provided, highlighting the main advantages and disadvantages in practice. Such pieces of information are crucial in order to present viable detection/monitoring methods prior to establishing MPs adverse effects and distinguishing whether these originate from MPs, present additives, or adsorbed additional pollutants. In order to enlighten and correlate current knowledge reflecting the toxicity of MPs, ecotoxicological studies employing different testing organisms are presented and critically discussed. It should be noted that this review focuses exclusively on freshwater studies because this path is the most common for the accumulation of MPs in the marine environment, except direct littering of plastic materials and consequent fragmentation thereof.

\section{Microplastics Types and Properties}

Plastics is a term, derived from Greek plastikos-meaning fit for molding [34], commonly used for a wide range of (semi-)synthetic polymers of high molecular weight. The most common types are: polyethylene (PE), polypropylene (PP), polyvinyl-chloride (PVC), polystyrene (PS), and polyethylene-terephthalate (PET) (Figure 1) [6,35], possessing specific physical, chemical, mechanical, optical, and electrical properties (Table 1). 
A<smiles>CCCCC(C)C</smiles>

D

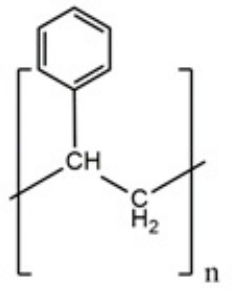

B<smiles>CCCC(C)CC(C)C</smiles>

C<smiles>CCC(Cl)C(Cl)CC</smiles>

E

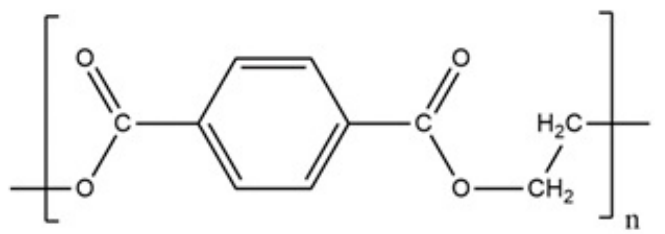

Figure 1. Chemical structures of: (A) polyethylene, (B) polypropylene, (C) polyvinyl-chloride, (D) polystyrene, and (E) polyethylene terephthalate.

Table 1. Physical and chemical properties of most used plastics.

\begin{tabular}{|c|c|c|c|c|c|}
\hline Types of Plastic & PE & $\mathbf{P P}$ & PVC & PS & PET \\
\hline $\begin{array}{l}\text { Density } \\
\left(\mathrm{g} \mathrm{cm}^{-3}\right)\end{array}$ & $\begin{array}{c}0.91-0.97[9,36] \\
0.91-0.92 \\
\left(23 / 4^{\circ} \mathrm{C}\right)[37]\end{array}$ & $\begin{array}{c}0.85-0.94[9] \\
0.89-0.92[36] \\
0.94-0.97 \\
\left(23 / 4^{\circ} \mathrm{C}\right)[37]\end{array}$ & $\begin{array}{c}1.38[9], \\
1.30-1.58[36], \\
1.35-1.45 \\
\left(23 / 4^{\circ} \mathrm{C}\right)[37]\end{array}$ & $\begin{array}{c}0.96-1.05[9] \\
1.04-1.05[36] \\
0.90-0.91 \\
\left(23 / 4^{\circ} \mathrm{C}\right)[37]\end{array}$ & $\begin{array}{c}1.34-1.39[9], \\
1.29[36] \\
1.03-1.09 \\
\left(23 / 4^{\circ} \mathrm{C}\right)[37]\end{array}$ \\
\hline $\begin{array}{c}\text { Melting } \\
\text { point }\left({ }^{\circ} \mathrm{C}\right)\end{array}$ & $\begin{array}{l}90-110[38], \\
98-130[36]\end{array}$ & $168-175[36]$ & 115-245 [39] & $\begin{array}{c}\text { none (atactic), } \\
240 \text { (isotactic), } \\
270 \text { (syndiotactic), [40] }\end{array}$ & $245[36]$ \\
\hline $\begin{array}{l}\text { Glass transition } \\
\text { temperature }\left({ }^{\circ} \mathrm{C}\right)\end{array}$ & -25 [36] & $\begin{array}{l}-10[36], \\
-20[41]\end{array}$ & $\begin{array}{c}75-105[36] \\
80-85[41] \\
\end{array}$ & $\begin{array}{c}74-105[36] \\
>80[41]\end{array}$ & $\begin{array}{l}73[36], \\
70[41]\end{array}$ \\
\hline Tensile strength (MPa) & $8-32$ [36] & $31-41[36]$ & $41-52[36]$ & $36-52[36]$ & $48[36]$ \\
\hline Crystallinity (\%) & $\begin{array}{c}45-95[9] \\
50[37]\end{array}$ & $\begin{array}{c}50-80[9], \\
65[41] \\
50[37]\end{array}$ & $\begin{array}{c}\text { High [9], } \\
5-15[41] \\
0[37]\end{array}$ & $\begin{array}{c}\text { Low [9], } \\
0 \text { [37] }\end{array}$ & $\begin{array}{c}\text { High [41], } \\
\text { 30-40 [42], } \\
0-50[37]\end{array}$ \\
\hline Lifespan (year) & $10-600$ [37] & $10-600[37]$ & 50-100 [37] & $50-80$ [37] & 450 [37] \\
\hline
\end{tabular}

Applications of polymers are determined, but not limited, by their properties. Applicative properties can be enhanced by the addition of accelerants, cross-linking additives, UV stabilizers, antidegradants, antioxidants, antiozonants, photosensitizers, surfactants, pigments, flame retardants, or plasticizers with biocidal additives [9]. Generally, plastics consist of crystalline and amorphous phases, affecting mechanical properties such as strength and elasticity. At a lower amount of amorphous phase, crystallinity and density increase. With the increase in the latter property, the elastic modulus, tensile strength, stiffness, and surface hardness also increase, but impact strength decreases [43].

$\mathrm{PE}$ is homopolymer consisting of long hydrocarbon repeated chains of ethylene monomer (Figure 1) and is used in a variety of products, e.g., plastic bags; bottles for milk, water, shampoo, or motor oils; toys; food packaging like yogurt cans, margarine containers or cereal box liners; irrigation and drainage pipes; various medical and cosmetic products $[38,44]$. It is not surprising that most commonly found plastics debris in freshwater ecosystems pertains to PE [6]. PE is classified as: (i) ultra-high, high or ultra-low molecular weight PE (UHMWPE, HMWPE or ULMWPE, respectively), (ii) high, high cross-linked, medium, linear low, low or very low-density PE (HDPE, HDLPE, MDPE, LLDPE, LDPE or VLDPE, respectively), or (iii) chlorinated PE [38]. PE is a good electrical insulator with 
low hardness, rigidity, and melting point, and high ductility and impact strength (Table 1). It has a lower density comparing to water (Table 1); thus, it is uncommon to be present in deep layers of aquatic ecosystems [6]. PE is very persistent in the environment due to its non-reactive $\mathrm{C}-\mathrm{C}$ and $\mathrm{C}-\mathrm{H}$ bonds, high molecular weight, hydrophobicity (allowing sorption on sediments or activated sludge) [6], and lack of functional groups that can be "recognized" by microbial enzymatic systems [45].

$\mathrm{PP}$ is a crystalline thermoplastic polymer with methyl-group on every subunit of polymer backbone (Figure 1); this improves its mechanical properties and thermal resistance. Linear PP has various structural isomers: isotactic, syndiotactic, and atactic. Isotactic PP has a greater degree of crystallinity than the other two; thus, it is less susceptible to biodegradation. A high degree of tacticity (iso- or syndio-) provides higher crystallinity, better mechanical properties, and chemical stability. A low degree of tacticity means lower hardness, strength, density, rigidity, stability, and melt fluidity. Commercial PP is approximately $90 \%$ isotactic with $60-70 \%$ crystallinity [43]. Comparing to HDPE, PP has some similar properties (permeability of gasses and vapor is almost the same), although differs in hardness, tensile strength, elasticity, transparency, and gloss (higher than HDPE). PP is highly resistant to water, inorganic chemicals, organic solvents, and lubricants; degradation occurs by strong oxidants [43]. PP is also a very good electrical insulator. Accordingly, it has numerous applications: as packaging material; medical and electronic equipment; furniture production; textile and automotive industries [6,10,38,44,46]. Hydrophobic surface and high molar mass of PP limit its biodegradation [37,47]. The insertion of hydrophilic groups onto the polymer surface via physical or chemical processes (e.g., degradation) is highly required to enable the attachment of microorganisms to such partially destructed polymer surface [48]. Accordingly, microorganisms can use low-molecular-weight fragments (oligomers), dimers, or monomers as carbon and energy sources [49], providing biodegradation. However, small oligomers may also diffuse into the organism and get assimilated, providing adverse effects [37].

PVC structure (Figure 1) contains heteroatom: chlorine, on every second C-atom of polymer backbone. PVC usage in Europe for packaging only exceeds 500,000 tons annually $[43,44]$. Due to its extreme versatility, PVC is irreplaceable for medicine equipment (blood bags, tubs for catheters, surgical gloves) and wall and floor coverings [46]. It is also used for construction purposes: piping, electrical cable insulation, doorframes, and windows [6,44]. PVC comes in two forms: (i) the rigid, which is used for food packaging, pharmaceutical, and medical products, and (ii) the flexible, which is used as a film for food wrappings due to its stretchability [43]. PVC is an excellent water and oxygen barrier; thus, packaged food may last longer ensuring its taste. PVC is resistant to chemicals but very sensitive to photodegradation [6]. Since its inception, PVC is a known polymer with exceptional resistance to biodegradation, making it an environmental issue; from production to waste disposal.

PS has an amorphous structure with a phenyl ring linked on every second C-atom of polymer backbone (Figure 1). It is well-known in its expanded form as Styrofoam and is used for packaging, bowls, containers, rigid trays, lids, and tumblers [43,44,50]. Global production of PS in 2013 was 21 MT [50]. PS is hard, stiff, durable, and transparent thermoplastic polymer, which is available in four forms: (i) general-purpose PS (GPPS), (ii) high impact PS (HIPS), (iii) PS foam, and (iv) expanded PS foam (EPS) [50,51]. Its foamed form is lightweight (it floats on the water surface), bulky, and recyclable [51]. PS is brittle and flammable with relatively low melting temperature and with a glass transition temperature of $>100{ }^{\circ} \mathrm{C}$; thus, it softens in boiling water. PS is poor oxygen and vapor barrier and sensitive to UV irradiation (it yellows) $[6,43]$.

PET (Figure 1) is, along with PE, one of the main food packaging materials. It is very common in the textile industry as well, where is commonly used in the following forms: (i) fiber filling in insulated clothing, furniture, and pillows, (ii) fine filaments in artificial silk, and (iii) large-diameter filaments in carpets production [7,43]. PET is used as/in yarns of vehicle tires; conveyer, drive or seat belt; reinforcement for fire and garden 
hoses; disposable medical clothing; synthetic fibers, bottles, containers, insulators, 3D printing filaments, and trays $[7,43,44]$. PET is transparent and colorless semi-crystalline thermoplastic polyester, strong and resistant to chemicals, and characterized by low vapor and gas permeability (Table 1) [52]. It is a good alternative for glass; thus, it is used for the production of bottles/containers for beverages [43]. PET is a major environmental pollution issue due to its high durability and low biodegradability. PET, similarly to PP and PS, has a hydrophobic surface, thus attenuating effective adsorption and access of hydrolytic enzymes (hydrolases, lipases, esterases, and cutinases) to accomplish polymer degradation [53].

\section{Sources of Microplastics in the Environment}

There are primary and secondary sources of MPs in the environment [5]. Primary include MPs deliberately manufactured for some products; i.e., textile (laundering of synthetic clothes providing $\sim 35 \%$ of primary microplastics), cosmetics (e.g., microbeads in facial scrubs $(\sim 2 \%)$ as intentionally added MPs in personal care products), electronic equipment $[13,35,54]$. Furthermore, abrasion of tires through driving $(28 \%)$, city dust $(24 \%)$, road making $(7 \%)$, marine coating $(3.7 \%)$, and plastic pellets $(0.3 \%)$ are also considered as the main sources of primary MPs. Most of these enter the environment through wastewater generated during the production or usage phases (Figure 2).

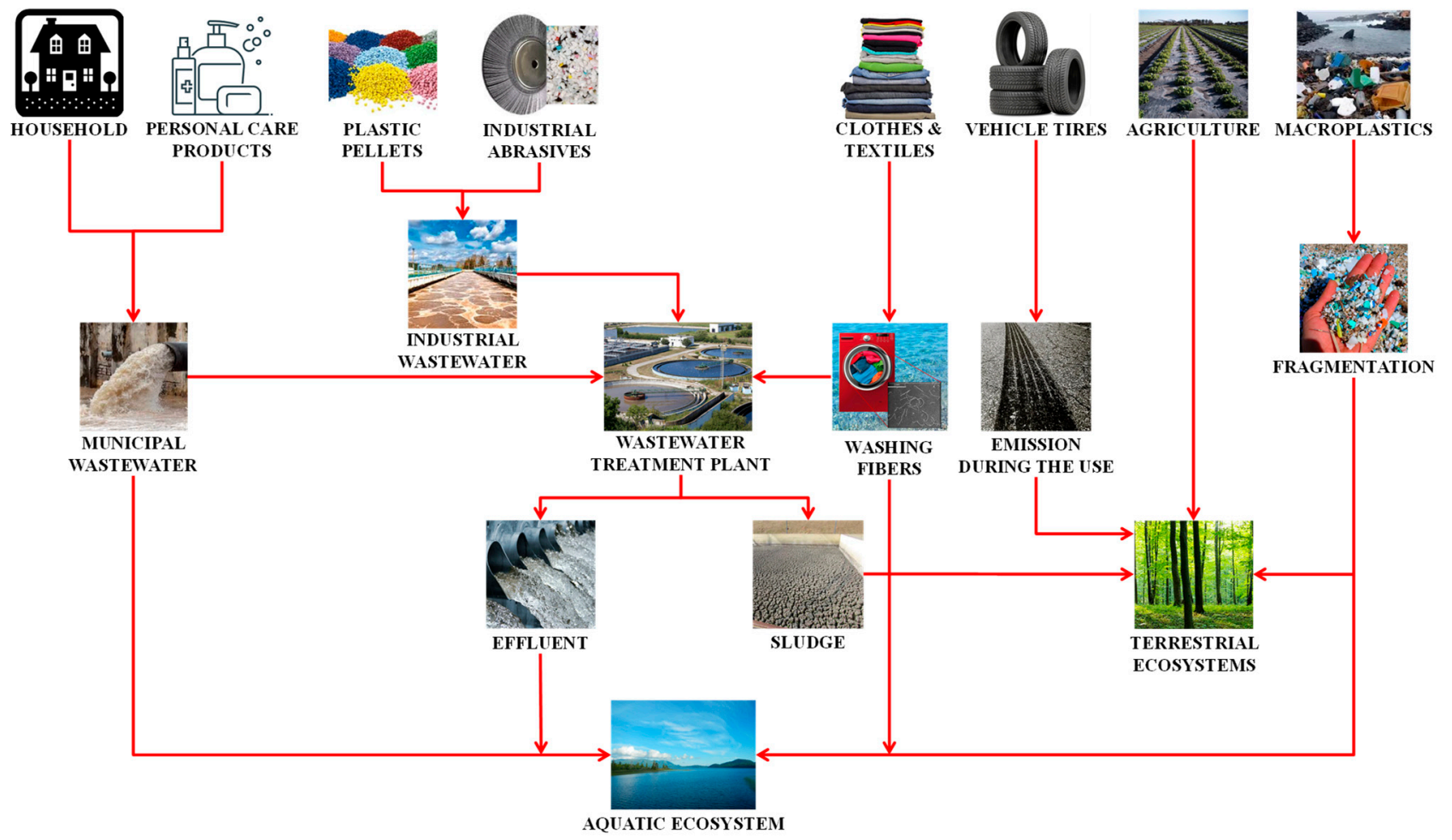

Figure 2. Sources of microplastics in the environment.

Secondary sources include a breakdown of larger plastic fragments such as plastic bags, bottles, or fishing nets introduced in the environment; the breakdown is caused by UV radiation, physical abrasion, chemical oxidation, and possibly biodegradation $[13,35,55,56]$.

Agriculture is one of the major entry points for MPs in the environment [57]; applications of sewage sludge, fertilizers/compost, soil conditioners, and vinyl coverings are the main sources. LDPE films, used in large volumes to protect agricultural crops, suppress weeds, increase temperature, and retain irrigation water in the soil, can be degraded into small fragments and end up in the soil or water resources through irrigation channels. The expanded PS flakes and polyurethane foam are used in horticulture to improve soil quality 
and as composting additive, respectively [58-60]. However, significant MPs amounts originate from various industries (through wastewaters or plastic residues disposal) and households (fibers from washing clothes, personal care products usage). Once released into the environment, MPs can be transported by wind, washed from land to surface waters during rainfall (stormwater run-off especially), and be transported in freshwater and seawater $[3,6,8,10,15,35,61]$. Industrial and municipal wastewaters are also main MPs sources, containing synthetic fibers (e.g., polyester, PES, produced in 2013 at >44.6 MT) [62]. Browne et al. [63] quantified that $>1900$ PES fibers are released during a single wash. Therefore, wastewaters containing MPs should be treated prior to discharging into the environment. However, only $\sim 60 \%$ of municipal wastewaters are treated [64]. Besides, wastewater treatment plants (WWTPs), commonly based on primary and secondary treatment units, are not designed to remove MPs. The tertiary treatment, including disinfection, is optional and irrelevant for MPs removal. After primary treatment application, including removal of material that either floats or readily settle out by gravity, wastewater may contain $>$ $20 \%$ of MPs [65]. Secondary treatment is biological; mixed consortium of microorganisms has a key role in forming activated sludge flocs. If MPs are retained within, there is a possibility to be released from flocs due to their instability in the aqueous phase. Although the efficiency of common WWTP for MPs removal is up to $95 \%$, a large MPs fraction is transferred into the activated sludge [65]. Moreover, WWTPs are not effective in removing particles $<10 \mu \mathrm{m}$ [15]; these remain in effluent and are consequently discharged into recipient natural aquatic systems. Besides technological, there are legislative issues too; Directive 91/271/EEC [66], which does not consider MPs monitoring in treated effluents or activated sludge, is still in force. Approximately 4-5 MT of activated sludge is applied to agricultural lands annually [14], thus providing additional MPs quantities in the environment. Upon entering freshwater sources, a fraction of MPs would be suspended in the water body, while others would deposit at the bottom of the water column (i.e., sediment). This process depends on the density of MPs; low-density MPs would float, while those with higher density would submerge [59]. The creation of biofilms may increase MPs density and consequently reduce their hydrophobicity, yielding their deposition to a higher extent. However, biofilms can carry pathogenic microorganisms (e.g., Vibrio or fecal coliforms) as well, which may present adverse effects on water biota and humans [67]. Moreover, MPs can also adsorb heavy metals and various CECs; e.g., polycyclic aromatic hydrocarbons, polybrominated diphenyl ethers, polychlorinated biphenyls, and dichlorodiphenyltrichloroethane $[68,69]$. MPs distribution may also be affected by particle aggregation and activity of animals [70]. MPs can be easily ingested by aquatic organisms of various trophic levels and can undergo biomagnification along the food chain [71]. MPs shapes and densities affect their availability to organisms; e.g., pelagic organisms (phytoplankton and zooplankton) are more likely to encounter less dense, floating MPs, while benthic organisms (amphipods, polychaete worms, tubifex worms, mollusks, and echinoderms) would encounter more dense MPs [56,70,72,73].

\section{Characterization Methods for Microplastics in the Environment}

MPs in the environment do not vary in chemical composition only, but in size, density, and shape of particles as well. These properties are important factors affecting fate, behavior, and transport of MPs in the environment [74]. MPs determination requires fast and reliable analytical methods, generally divided into two steps: (i) extraction and digestion of organic fraction, and (ii) MPs detection, quantification, and characterization [75]. Various analytical techniques have been used for MPs determination from different angles. However, none of these is comprehensive, i.e., two or more methods should be used to get full insight into MPs properties, especially when monitoring MPs (bio)activity. In such case, methods able to detect changes in MPs structure (e.g., based on spectroscopy and chromatography techniques) are more beneficial than those providing insight mainly into surface and morphology changes (e.g., based on microscopy techniques). 


\subsection{Microscopy Based Methods}

Visual identification by binocular (polarized) microscope (BM) is used to detect the physical characterization of MPs differing in color, shape, surface texture, or size. MPs come in eight common shapes [74]: fibers, spheres, pellets, lines, sheets, flakes, foam, and fragments-the latter is the most abundant shape. A visual approach is also useful to distinguish MPs from other particles of similar size and shape (e.g., clay or algae), and for particle counting [76]. Larger particles (size in a range from 1 to $5 \mathrm{~mm}$ ) can be analyzed even by the naked eye, but there is a possibility of missing small and transparent MP particles in the samples. Analysis of smaller particles requires the application of a microscope [35,77]; Lee et al. [78] reported $1 \mathrm{~mm}$ in size as a detection threshold without a microscope. Sierra et al. [79] identified different MPs from wastewater by polarized light microscopy (PLM) and provided further confirmation by non-focal Raman microscopy. Polarized light enables the classification of materials with a certain type of anisotropy; under cross polars, they look bright. There is also strong evidence that visual sorting is not a very reliable method. Namely, Hidalgo-Ruz et al. [80] reported that $70 \%$ of visually sorted particles were not identified as plastic when additional FTIR analysis was performed. Method using PLM is limited in MPs identification from non-birefringent polymers such as PVC. Nevertheless, the visual approach is simple, economical, and can be implemented in situ in a short time. However, it does not provide information about chemical composition. In summary, the visual approach can provide information about MPs abundance and even the size, which might be quite helpful when assessing adverse effects caused by MPs presence. However, in practice, more reliable techniques for MPs identification are used (spectroscopy or chromatography) to obtain more relevant information due to the high possibility of misjudgment [15,76].

Scanning Electron Microscopy (SEM) is used for the determination of MPs size, shape, surface changes, and roughness, as well as to confirm bacterial biofilm formation on MPs surface. Samples for SEM analysis (i) must be in solid state, non-radioactive, and non-magnetic, (ii) cannot contain moisture, (iii) have to possess stable composition, and (iv) need to be coated at high vacuum [81]. The surfaces of MPs are scanned by an electron beam to obtain clear images, high magnification, and high resolution of MP surfaces [81]. Accordingly, great insights of MP surfaces are obtained, allowing to achieve a more precise identification of MPs. SEM can be coupled with energy-dispersive X-ray spectroscopy (SEM-EDS), producing high-resolution images of particles and providing an elemental analysis of measured objects. Thus, it is possible to distinguish MPs from inorganic particles [82]. Trace elements (like $\mathrm{Al}, \mathrm{Na}, \mathrm{Ca}, \mathrm{Mg}$, or $\mathrm{Si}$ ) can be identified as well, indicating the presence of additives or particles adsorbed on MPs surface [12,82]. Accordingly, SEM-EDS may also provide the evidence for adsorbed heavy metals (e.g., $\mathrm{Cd}, \mathrm{Cr}, \mathrm{Pb}, \mathrm{Zn}, \mathrm{Ni}$ ) onto MPs. However, it should be also pointed out that in the case of nonconductive samples such MPs, the covering of a sample surface with a very thin layer of carbon by high vacuum evaporation coating or gold or gold/palladium alloy or platinum thin film using a plasma sputter coater is highly necessary [83]. Hence, the carbon covering may provide interference during elemental analysis. More relevant results on MPs identification can be achieved by combining SEM-EDS with spectroscopic methods such as Raman or Fourier transform-infrared spectroscopy (FTIR). Mehdinia et al. [84] combined three observation techniques to identify MPs: (i) color, size, and morphology were determined by PLM, (ii) SEM-EDS was used for specific structure, morphological properties, and chemical composition of individual MPs, and (iii) Raman spectroscopy has been applied to determine polymer types.

\subsection{Spectroscopy-Based Methods}

FTIR allows accurate identification of polymers from their characteristic IR spectra due to the possession of specific IR spectra with distinct band patterns [85]. FTIR is the most frequently used method for MPs analysis [86]. When a plastic polymer is irradiated with IR, a certain amount of energy gets absorbed by the polymer molecule, causing 
molecular vibrations that yield a characteristic IR spectrum. Vibrations depend on the polymer structure and applied irradiation wavelengths [85]. Generally, FTIR analysis is performed in mid-IR range of $4000-400 \mathrm{~cm}^{-1}$ [87]. Generally, plastic materials lose weight during degradation, indicating structural changes [88]. Hence, polymer degradation may be confirmed by the analysis of its functional groups; some groups are missing or possess lower or higher peak intensity in comparison to reference FTIR spectra $[15,89]$. Typical vibrational bands of PE, PP, PVC, PET, and PS are summarized in Table 2.

Table 2. Functional groups of the most used polymers and their wavenumbers in FTIR spectra [90-93].

\begin{tabular}{|c|c|c|}
\hline Polymer & Functional Group & Wavenumber $\left(\mathrm{cm}^{-1}\right)$ \\
\hline \multirow{7}{*}{ PE } & $\mathrm{CH}_{2}$ symmetric stretch & $2918 ; 2850$ \\
\hline & $\mathrm{CH}_{2}$ asymmetric stretch & 2919 \\
\hline & $\mathrm{CH}_{2}$ bend & $1473 ; 1463$ \\
\hline & $\mathrm{CH}_{3}$ symmetric stretch & 1377 \\
\hline & $\mathrm{CH}_{2}$ wag & $1366 ; 1351 ; 1176$ \\
\hline & $\mathrm{CH}_{2}$ twist & 1050 \\
\hline & $\mathrm{CH}_{2}$ rock & $731-720$ \\
\hline \multirow{18}{*}{ PP } & $\mathrm{CH}_{2}$ asymmetric stretch & 2919 \\
\hline & $\mathrm{CH}_{3}$ asymmetric stretch & 2951 \\
\hline & $\mathrm{CH}_{3}$ symmetric stretch & 2868 \\
\hline & $\mathrm{CH}_{2}$ symmetric stretch & 2837 \\
\hline & $\mathrm{CH}_{2}$ scissors & 1458 \\
\hline & $\mathrm{CH}_{3}$ symmetric bend, $\mathrm{CH}_{2}$ wag & 1377 \\
\hline & $\mathrm{CH}$ bend, $\mathrm{CH}_{2}$ twist, $\mathrm{CH}_{3}$ rock & 1256 \\
\hline & $\mathrm{CH}_{2}$ twist, $\mathrm{C}-\mathrm{C}$ stretch, $\mathrm{C}-\mathrm{H}$ bend & 1220 \\
\hline & $\mathrm{CH}$ bend, $\mathrm{CH}_{3}$ rock, $\mathrm{C}-\mathrm{C}$ stretch & 1168 \\
\hline & $\mathrm{C}-\mathrm{C}$ stretch, $\mathrm{CH}_{3}$ rock, $\mathrm{CH}_{2}$ wag, $\mathrm{CH}$ twist, $\mathrm{CH}$ bend & 1104 \\
\hline & $\mathrm{C}-\mathrm{CH}_{3}$ stretch, $\mathrm{C}-\mathrm{C}$ stretch, $\mathrm{CH}$ bend & 1045 \\
\hline & $\mathrm{CH}_{3}$ rock, $\mathrm{CH}_{3}$ wag, $\mathrm{CH}$ bend & 998 \\
\hline & $\mathrm{CH}_{3}$ rock, $\mathrm{C}-\mathrm{C}$ stretch & 941 \\
\hline & $\mathrm{CH}_{3}$ rock & 937 \\
\hline & $\mathrm{CH}_{3}$ rock, $\mathrm{CH}_{3}$ rock, $\mathrm{CH}$ bend & 899 \\
\hline & $\mathrm{CH}_{2}$ rock, $\mathrm{C}-\mathrm{CH}_{3}$ stretch & 841 \\
\hline & $\mathrm{CH}_{2}$ rock, $\mathrm{C}-\mathrm{C}$ stretch, $\mathrm{C}-\mathrm{CH}$ stretch & 809 \\
\hline & $\mathrm{CH}_{2}$ rock & $730 ; 720$ \\
\hline \multirow{7}{*}{ PVC } & $\mathrm{CH}_{2}$ asymmetric stretch & 2904 \\
\hline & $\mathrm{CH}_{2}$ symmetric stretch & 2837 \\
\hline & $\mathrm{CH}_{2}$ wag & 1354 \\
\hline & $\mathrm{CH}$ bend & $1333 ; 1254 ; 1243$ \\
\hline & C-C stretch & 1099 \\
\hline & $\mathrm{CH}_{2}$ rock & $970 ; 957$ \\
\hline & $\mathrm{C}-\mathrm{Cl}$ stretch & 603 \\
\hline \multirow{12}{*}{ PET } & $\mathrm{CH}_{2}$ asymmetric stretch & 2969 \\
\hline & $\mathrm{C}=\mathrm{O}$ stretch & $1740-1710$ \\
\hline & $\mathrm{CH}_{2}$ bend & 1470 \\
\hline & $\mathrm{CH}_{2}$ wag & $1370-1340$ \\
\hline & C-C-O asymmetric stretch bonded to aromatic ring & 1250 \\
\hline & C-O stretch & 1260 \\
\hline & $\mathrm{C}-\mathrm{O}-\mathrm{C}$ stretch & 1100 \\
\hline & aromatic in-plane $\mathrm{CH}$ bend & 1019 \\
\hline & oxy-methylene group bend & 973-898 \\
\hline & aromatic out-of-plane $\mathrm{CH}$ wag & 875 \\
\hline & $\mathrm{C}=\mathrm{O}$ rock, $\mathrm{C}-\mathrm{O}$ deformation & 795 \\
\hline & aromatic in-phase $\mathrm{CH}$ wag & 730 \\
\hline
\end{tabular}


Table 2. Cont.

\begin{tabular}{ccc}
\hline Polymer & Functional Group & Wavenumber $\left.\mathbf{c m}^{-\mathbf{1}}\right)$ \\
\hline & $\mathrm{CH}_{2}$ asymmetric stretch & 2924 \\
$\mathrm{CH}_{2}$ symmetric stretch & 2850 \\
$\mathrm{CH} \mathrm{CH}_{2}$ bend & 1451 \\
aromatic CH stretch & 3024 \\
& aromatic ring stretch & $1604 ; 1492$ \\
& aromatic CH bend & 1027 \\
\hline
\end{tabular}

One disadvantage of FTIR analysis is that bands of organic and inorganic impurities can overlap with polymer bands in IR spectra, hindering spectroscopic evaluation [94]. Accordingly, samples should be pretreated before analysis in order to remove moisture, which may cause interference resulting in data interpretation difficulties $[15,81]$. Transmission IR spectroscopy is used for thin and transparent samples, while the reflection mode is usually employed for thick and non-transparent samples. Attenuated total reflectance FTIR (ATR-FTIR) is a common FTIR technique measuring IR spectrum of polymer's surface, or a spectrum of thick and strongly absorbing polymers [95]. ATR-FTIR is appropriate for the analysis of somewhat larger particles (above $500 \mu \mathrm{m}$ ) [15], although various ATR accessories provide magnification, enabling the viewing down to $70 \mu \mathrm{m}$ [87]. ATR-FTIR was successfully applied for the identification of MPs in surface waters and sediments [76]. This method is generally cheaper; however, it is unable to identify small samples and convex particles [9]. Microscopy coupled FTIR ( $\mu$-FTIR) has improved spatial resolution [96] and is commonly applied for MPs analysis of $<100 \mu \mathrm{m}$ [87]. Its applicability for the identification of MPs presents directly on membrane filters is especially interesting [96]. Käppler et al. [94] applied $\mu$-ATR-FTIR and Pyrolysis-Gas Chromatography-Mass Spectrometry (Pyr-GC-MS) in combination with thermochemolysis to characterize 27 single MPs particles and fibers of unknown material isolated from river sediments. The study showed that both methods are well suited to characterize the chemical nature of environmental MPs and can complement each other. Focal plane array-based $\mu$-FTIR (FPA- $\mu$-FTIR) utilizes focal plane array detectors and, due to simultaneous acquiring of a higher number of spatially resolved spectra, provides much faster identification. It can be applied for smaller MPs and at a much larger surface area [96].

Raman spectroscopy uses a characteristic Raman spectrum for the identification of MPs; the polymer is irradiated with monochromatic rays (from 500-800 nm). Once the ray comes to the target, it interacts with polymer absorbing a certain amount of the ray's energy. Consequently, Raman shift occurs, i.e., the frequency of backscattered light becomes different than input, providing a characteristic Raman spectrum of the polymer [85]. The obtained spectrum must be compared with a reference spectrum to perform identification [35]. Raman provides a complementary image of molecular vibrations to FTIR, while FTIR is sensitive to vibrations that modulate molecular dipole moment, Raman is sensitive to those that modulate molecular polarizability [95]. Raman spectroscopy offers a wide spectral range, great resolution (due to reduced linewidth between bands that are close to each other in the spectrum), and low water interference [97]. Accordingly, Raman is a powerful technique for MPs analysis not only in water samples; it is suitable for sediment, organisms, food, and cosmetics as well [86]. Furthermore, it requires a small amount of sample, providing a possibility for high throughput screening. It can resolve very small particles $(<1 \mu \mathrm{m})$. Unfortunately, Raman is highly sensitive to sample fluorescence, which can spoil the useful Raman signal. In addition, laser-induced degradation may occur when fluorescence is caused by impurities present in the sample. This may negatively affect the sample, speaking in favor of the necessity of the sample pretreatment prior to analysis [97]. However, it remains the most preferred technique for MPs analysis for particles $<10 \mu \mathrm{m}$ [85]. Accordingly, Raman was successfully used for MPs identification in sediment [98], seawater [99], freshwater [100], wastewater [101], and aquatic organisms [102]. 


\subsection{Chromatography-Based Methods}

Pyr-GC-MS is a destructive but efficient method for structural MPs identification, focused on pyrolytic degradation of the sample (only 5-200 $\mu \mathrm{g}$ ) and analysis of byproducts. Polymer (sub-)type(s) and organic additives can be efficiently identified according to their mass [76]. However, the number and morphology of MPs cannot be encountered and determined, respectively, thus requiring the combination with microscopy methods (e.g., visual inspection by BM or PLM and/or SEM).

Thermal extraction-desorption Gas Chromatography-Mass Spectrometry (TED-GCMS) is a two-step analytical method ideally suited for the analysis of polymers and their degradation intermediates. The primary step includes the thermal decomposition of sample (performed in the thermogravimetric analyzer, TGA), followed by the collection of resulting gaseous products on a solid-phase adsorber. Thereafter, the adsorbent is analyzed by TED-GC-MS [103]. The method does not require preselection of MPs as in the case of Pyr-GC-MS [76].

High-performance liquid chromatography (HPLC) can be also applied for MPs identification in environmental water systems. However, MPs particles must be dissolved prior to the analysis using organic solvents. Tetrahydrofurane and hexafluoroisopropanol are solvents used for PS and PET, respectively [15], while other polymers (PE, PP, and PVC) are commonly analyzed on GC-MS.

To conclude, there are several options to perform the characterization of MPs in the environment; however, as MPs may vary in chemical composition, size, density, and shapes, as well as they are present in various water matrices, a unique method does not exist. The above methods have some advantages over another regarding the particular MPs targeted property; however, if a thorough analysis is required, a combination of methods have to be applied. For example, visual inspection by the naked eye is always a good choice as the first step; however, a visual inspection cannot be the only method. It has to be combined with more powerful inspection techniques, e.g., SEM-EDS if the size, shape, and morphology of MPs are targets of inspection. Furthermore, in order to confirm whether observed particles all belong to MPs or not, FTIR and its more advanced analogs, or more powerful, but more expensive technique, Raman analysis is required. However, both have their disadvantages; e.g., in FTIR moisture causes interference, while fluorescence may occur in the case of Raman analysis. Regardless, both methods would provide fingerprinting of present plastic materials regarding their composition. The methods based on chromatography coupled with mass spectroscopy may provide more insights into additives in MPs samples, besides their core plastic materials, which may be effectively identified by FTIR or Raman, which is rather important when monitoring MPs degradation and potential adverse effects that may be originated by present additives/intermediates. Hence, although the preparation of samples is often more complicated and analysis lasts longer than with FTIR or Raman, methods based on chromatography are highly required in MPs characterization as well. Thus, further development of currently existing methods or completely new ones for MPs identification and characterization is highly necessary due to their ubiquitous presence in the environment, as well as to provide a reliable assessment of ecological risks of MPs on aquatic organisms.

\section{Ecotoxicological Effects on Microplastics}

Ecotoxicological studies on MPs can be distinguished according to: (i) test organisms, (ii) type, shape, and size of the polymer, and (iii) the site of analysis (in situ or in laboratory). There are numerous organisms that can be used in MPs ecotoxicological assessment; however, $>75 \%$ of studies were performed on marine (micro)organisms. The most common testing organisms applied are: fish, mollusks, small and large crustaceans, annelids, mammals and echinoderms, birds and cnidarians, sponges, reptiles, and rotifers. Fish is mostly used in in situ studies, while small crustaceans prevail among organisms tested in a laboratory $[4,19,22,23,29,104-110]$. The most studied MPs shapes include spherical particles, fibers, and fragments. Although PE and PS are the most studied MPs types (due 
to their ubiquitous presence in aquatic ecosystems), investigations also comprehended ecotoxicological effects of other MPs types such as PP, PES/PET, PVC, polyamide, acrylic, polyether, cellophane, and polyurethane [22].

Regardless of MP types, both direct and indirect toxic effects on aquatic organisms have been investigated. Results of ecotoxicological studies are commonly expressed as a concentration of tested compounds causing certain effects (in percentage) on measured population. The most common effect considered within these studies was the percentage of population mortality. Hence, in lethal toxicity testing, $\mathrm{LD}_{50}$ represents the median lethal dose, while $\mathrm{LC}_{50}$ represents the median lethal concentration. If a test end point is an adverse response other than death, an effective concentration (EC) or effective dose (ED) is used toxicity parameter. Concentration causing $50 \%$ of adverse effect in the tested population is commonly used $\left(\mathrm{EC}_{50}\right)$, although other levels (i.e., $\mathrm{EC}_{10}$ [111] or $\mathrm{EC}_{20}$ [112]) can be applied if necessary. Effective and lethal values can be expressed per mass of tested organism; ED and LD are used for higher organisms. Besides, it is also possible to determine the No Observed Adverse Effect Level (NOAEL) and Lowest Observed Adverse Effect Level (LOAEL). NOAEL is the highest exposure level at which there are no biologically significant increases in the frequency or severity of adverse effect between the exposed population and its appropriate control; some effects may be produced at this level, but they are not considered as adverse. LOAEL is the lowest exposure level at which there are biologically significant increases in frequency or severity of adverse effects between the exposed population and its appropriate control group. Growth inhibition test is used for the ecotoxicological purpose as well [113]. Table 3 summarizes ecotoxicological studies performed including (micro)organisms and MPs types used.

MPs toxicological effects on freshwater aquatic (micro)organisms are still scarce since most studies applied marine (micro)organisms. Therefore, future studies should be focused on freshwater microorganisms such as algae and bacteria or other surface water and sediment organisms. Current data summarized in Table 3 reveal that researches are performed using a wide range of concentrations and types of MPs to study adverse effects to the range of organisms (from bacteria to fish). Accordingly, the graphical presentation in Figure 3 shows the range of ecotoxicological concentrations established for different organism levels studied, thus providing an insight into the sensitivity of tested organisms to changes in MPs concentrations affecting different trophic levels.

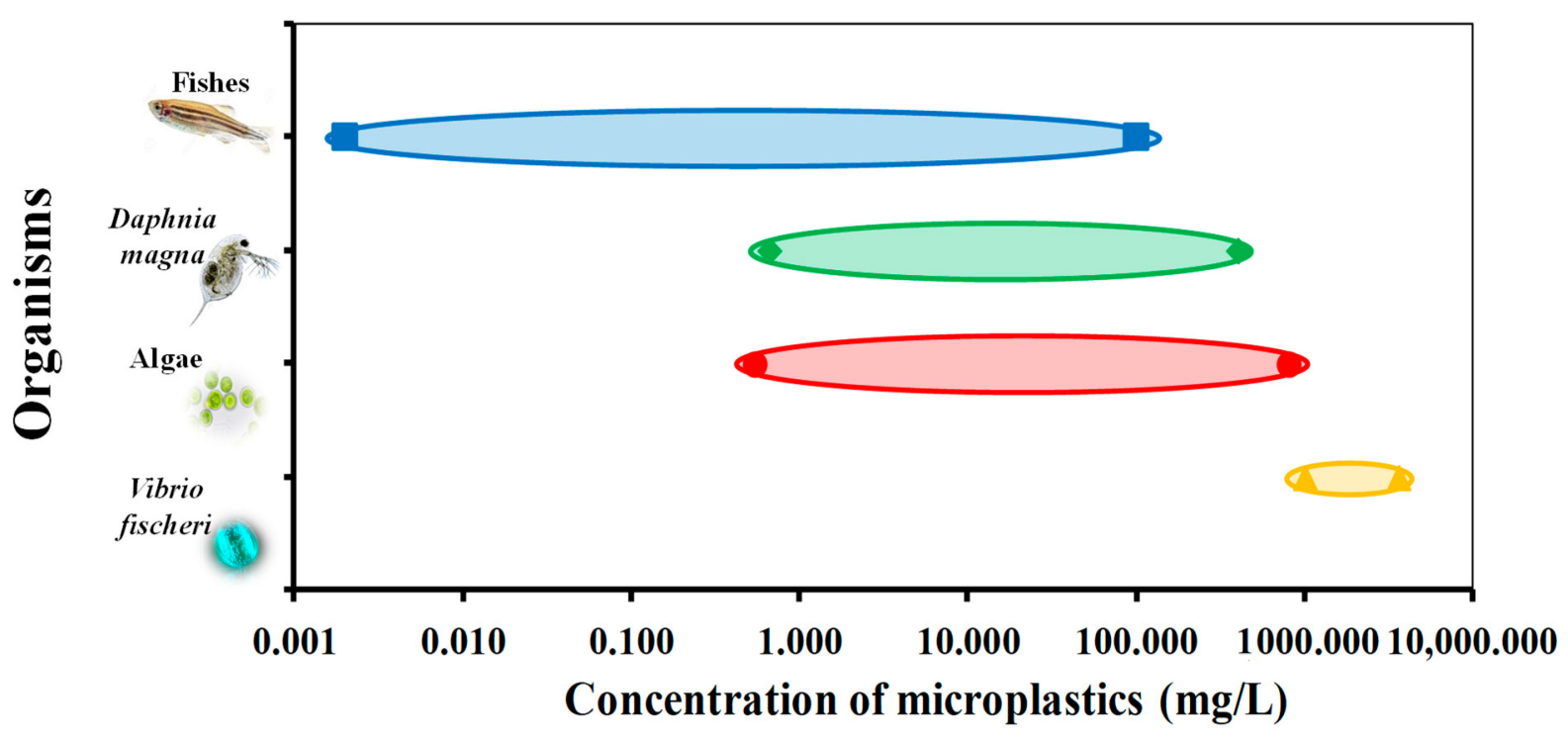

Figure 3. The range of ecotoxicological concentrations for different organism levels. 
Table 3. Parameters given by different ecotoxicological studies.

\begin{tabular}{|c|c|c|c|c|c|c|}
\hline Microorganism/ Organism & Type of MPs & Size of MPs & Concentration of MPs & Parameters Value & Effects & References \\
\hline \multirow{3}{*}{ Vibrio fischeri } & PE & $1.00-3.00 \mu \mathrm{m}$ & $1000.0 \mathrm{mg} / \mathrm{L}$ & $\begin{aligned} \mathrm{EC}_{20}= & 3600.0 \mathrm{mg} / \mathrm{L} \\
& (5 \mathrm{~min}) \\
\mathrm{EC}_{20}= & 2600.0 \mathrm{mg} / \mathrm{L} \\
& (30 \mathrm{~min})\end{aligned}$ & \multirow{3}{*}{ ecrease of bioluminescence } & [112] \\
\hline & \multirow{2}{*}{ PS-PEI ${ }^{a}$} & $0.06 \mu \mathrm{m}$ & \multirow{2}{*}{$3.0-1000.0 \mathrm{mg} / \mathrm{L}$} & $\mathrm{EC}_{50}=\underset{(30 \mathrm{~min})}{\geq 1000.0 \mathrm{mg} / \mathrm{L}}$ & & \multirow{2}{*}{ [113] } \\
\hline & & $0.11 \mu \mathrm{m}$ & & $\mathrm{EC}_{50}=\underset{(30 \mathrm{~min})}{\geq 1000.0 \mathrm{mg} / \mathrm{L}}$ & & \\
\hline \multirow{2}{*}{$\begin{array}{c}\text { Algae } \\
\text { Pseudokirchneriella subcapitata }\end{array}$} & \multirow{2}{*}{ PS-PEI ${ }^{\mathrm{a}}$} & $0.06 \mu \mathrm{m}$ & $0.1-1.0 \mathrm{mg} / \mathrm{L}$ & $\mathrm{EC}_{50}=0.58 \pm 0.04 \mathrm{mg} / \mathrm{L}(72 \mathrm{~h})$ & \multirow{2}{*}{ inhibition of algal growth } & \multirow{2}{*}{ [113] } \\
\hline & & $0.11 \mu \mathrm{m}$ & $0.1-0.8 \mathrm{mg} / \mathrm{L}$ & $\mathrm{EC}_{50}=0.54 \pm 0.06 \mathrm{mg} / \mathrm{L}(72 \mathrm{~h})$ & & \\
\hline Chlorella sp. & \multirow{2}{*}{ PS } & \multirow{2}{*}{$0.02 \mu \mathrm{m}$} & \multirow{2}{*}{$80.0-800.0 \mathrm{mg} / \mathrm{L}$} & $k^{\mathrm{b}}=3918.0(\mathrm{mg} / \mathrm{L})^{1-\mathrm{n}}$ & \multirow{2}{*}{$\begin{array}{c}\text { adsorption of particles on algae, } \\
\text { reduction of photosynthesis, } \\
\text { oxidative stress }\end{array}$} & \multirow{2}{*}{ [114] } \\
\hline Scenedesmus sp. & & & & $k^{\mathrm{b}}=4309.0(\mathrm{mg} / \mathrm{L})^{1-\mathrm{n}}$ & & \\
\hline \multirow{2}{*}{ Scenedesmus sp. } & \multirow{2}{*}{ PS } & $0.10 \mu \mathrm{m}$ & \multirow{2}{*}{$\begin{array}{c}10.0,50.0 \text { and } \\
100.0 \mathrm{mg} / \mathrm{L}\end{array}$} & $\mathrm{IR}^{\mathrm{c}}=21.0,29.0,38.5 \%$ & \multirow{2}{*}{$\begin{array}{l}\text { inhibition of algal growth, } \\
\text { morphological changes, oxidative stress }\end{array}$} & \multirow{2}{*}{ [115] } \\
\hline & & $1.00 \mu \mathrm{m}$ & & $\mathrm{IR}^{\mathrm{c}}=20.9,28.4,38.1 \%$ & & \\
\hline Chlorella pyrenoidosa & PVC & $111.0-216.0 \mu \mathrm{m}$ & \multirow{3}{*}{$\begin{array}{l}5.0,10.0,50.0,100.0 \\
250.0,500.0 \mathrm{mg} / \mathrm{L}\end{array}$} & $\begin{array}{c}\mathrm{IR}_{\mathrm{a}} \mathrm{d}=20.39,37.67,49.46,48.49 \\
55.23,55.17 \%\end{array}$ & \multirow{3}{*}{$\begin{array}{l}\text { decrease of chlorophyll a content and } \\
\text { photosynthetic activity }\end{array}$} & \multirow{3}{*}{ [116] } \\
\hline \multirow{2}{*}{ Microcystis flos-aquae } & $\mathrm{PP}$ & $64.00-236.00 \mu \mathrm{m}$ & & $\begin{array}{c}\mathrm{IR}_{\mathrm{a}}^{\mathrm{d}}=11.13,1.29,10.52,13.13 \\
13.06,16.92 \%\end{array}$ & & \\
\hline & PVC & $111.0-216.0 \mu \mathrm{m}$ & & $\begin{array}{c}\mathrm{IR}_{\mathrm{a}} \mathrm{d}=9.55,24.92,23.97,18.61 \\
32.20,46.93 \%\end{array}$ & & \\
\hline Chlamydomas reinhardtii & $\mathrm{PP}$ & $400.0-1000.0 \mu \mathrm{m}$ & $400.0 \mathrm{mg} / \mathrm{L}$ & $\mathrm{IR}^{\mathrm{c}}=\sim 18.0 \%$ (78 days) & $\begin{array}{l}\text { inhibition of algal growth, formation of } \\
\text { hetero-aggregates }\end{array}$ & [117] \\
\hline \multirow{2}{*}{ Daphnia magna } & \multirow{2}{*}{ PS-PEI ${ }^{a}$} & $0.06 \mu \mathrm{m}$ & \multirow{2}{*}{$0.33-3.30 \mathrm{mg} / \mathrm{L}$} & $\begin{array}{c}\mathrm{EC}_{50}=0.77 \pm 0.10 \mathrm{mg} / \mathrm{L} \\
(48 \mathrm{~h})\end{array}$ & \multirow{2}{*}{ immobilization rate } & \multirow{2}{*}{ [113] } \\
\hline & & $0.11 \mu \mathrm{m}$ & & $\begin{array}{c}\mathrm{EC}_{50}=0.66 \pm 0.17 \mathrm{mg} / \mathrm{L} \\
(48 \mathrm{~h})\end{array}$ & & \\
\hline
\end{tabular}


Table 3. Cont.

\begin{tabular}{|c|c|c|c|c|c|c|}
\hline $\begin{array}{l}\text { Microorganism/ } \\
\text { Organism }\end{array}$ & Type of MPs & Size of MPs & Concentration of MPs & Parameters Value & Effects & References \\
\hline & \multirow{2}{*}{ PS } & $1.0 \mu \mathrm{m}$ & $0.1-600.0 \mathrm{mg} / \mathrm{L}$ & $\begin{array}{l}\mathrm{EC}_{50}=66.97 \mathrm{mg} / \mathrm{L}(48 \mathrm{~h}) \\
\mathrm{LC}_{50}=87.83 \mathrm{mg} / \mathrm{L}(48 \mathrm{~h})\end{array}$ & \multirow{2}{*}{$\begin{array}{l}\text { immobilization rate, oxidative } \\
\text { stress, mortality }\end{array}$} & \multirow{2}{*}{ [118] } \\
\hline & & $10.0 \mu \mathrm{m}$ & $0.01-40.0 \mathrm{mg} / \mathrm{L}$ & $\begin{array}{l}\mathrm{EC}_{50}=199.94 \mathrm{mg} / \mathrm{L}(48 \mathrm{~h}) \\
\mathrm{LC}_{50}=291.69 \mathrm{mg} / \mathrm{L}(48 \mathrm{~h})\end{array}$ & & \\
\hline & $\mathrm{PE}$ & $1.0 \mu \mathrm{m}$ & $\begin{array}{l}12.5,25.0,50.0,100.0 \\
200.0 \text { and } 400.0 \mathrm{mg} / \mathrm{L}\end{array}$ & $\begin{array}{c}\mathrm{ID}^{\mathrm{e}}=25.00 \% \pm 1.91 \\
35.00 \% \pm 1.00,55.00 \% \pm 1.00 \\
50.00 \% \pm 2.58,75.00 \% \pm 1.00 \\
35.00 \% \pm 1.91(96 \mathrm{~h})\end{array}$ & $\begin{array}{l}\text { immobilization rate, } \\
\text { accumulation in gut }\end{array}$ & [119] \\
\hline & $\mathrm{PE}$ & $1.00-5.00 \mu \mathrm{m}$ & $\begin{array}{c}\text { 3.0, } 4.0,5.0,6.0 \text { and } 7.0^{\mathrm{f}} \\
\text { particles } / \mathrm{mL}\end{array}$ & 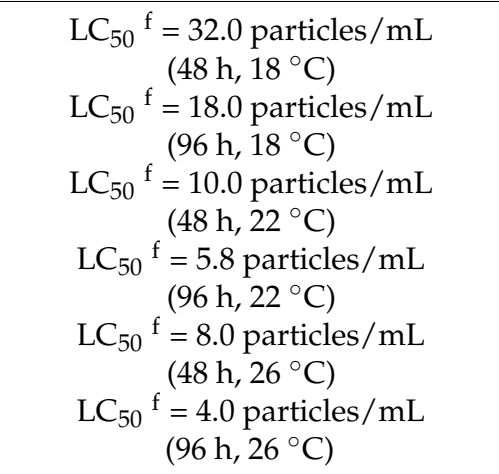 & immobilization rate, mortality & [120] \\
\hline & PET & $\begin{array}{l}\text { fibers of } 20.0 \mu \mathrm{m} \\
\text { thickness }\end{array}$ & $12.5-100.0 \mathrm{mg} / \mathrm{L}$ & $\begin{array}{c}\mathrm{EC}_{50}=1.34 \mathrm{mg} / \mathrm{L}(24 \mathrm{~h}) \\
\text { mortality was in the range } \\
20.0-40.0 \% \text { for } 12.5-100.0 \mathrm{mg} / \mathrm{L}\end{array}$ & $\begin{array}{l}\text { immobility, accumulation } \\
\text { in gut, mortality }\end{array}$ & [121] \\
\hline \multirow{2}{*}{$\begin{array}{l}\text { Fish } \\
\text { Danio rerio }\end{array}$} & PE & $140.6 \pm 80.0 \mu \mathrm{m}$ & $100 \mathrm{mg} / \mathrm{L}$ & $\begin{array}{c}75.0 \% \text { deformed embryos } \\
\text { (96 h, aged MP in WWTP effluent) } \\
E C_{50} \leq 1.0 \% \\
\text { (96 h, aged MP in landfill leachate) }\end{array}$ & impact on development & [122] \\
\hline & $\begin{array}{l}\text { PE, PP, PS, } \\
\text { and PVC }\end{array}$ & $0.10,1.0$ and $5.0 \mu \mathrm{m}$ & $0.001-10.0 \mathrm{mg} / \mathrm{L}$ & $\begin{array}{c}\mathrm{SP}^{\mathrm{g}}=73.0 \% \pm 24.0 \\
(\mathrm{PP}, \text { after } 10 \text { days, at } 10.0 \mathrm{mg} / \mathrm{L}) \\
\text { SP } \mathrm{g}=83.0 \% \pm 24.0 \\
(\mathrm{PVC}, \text { after } 10 \text { days, at } 10.0 \mathrm{mg} / \mathrm{L})\end{array}$ & $\begin{array}{l}\text { morphological deformations, damage } \\
\text { of the intestine, mortality }\end{array}$ & [123] \\
\hline
\end{tabular}


Table 3. Cont.

\begin{tabular}{|c|c|c|c|c|c|c|}
\hline $\begin{array}{c}\text { Microorganism/ } \\
\text { Organism }\end{array}$ & Type of MPs & Size of MPs & Concentration of MPs & Parameters Value & Effects & References \\
\hline & PS & $\begin{array}{l}45.0 \mu \mathrm{m} \\
0.05 \mu \mathrm{m}\end{array}$ & $1.0 \mathrm{mg} / \mathrm{L}$ & $\begin{array}{c}22.0 \%, 6.1 \% \text { suppressed locomotor } \\
\text { ability, body length during } \\
\text { exposure at } 0.05 \mu \mathrm{m} \\
\text { particles, respectively }\end{array}$ & $\begin{array}{l}\text { suppressed locomotor activity, decrease } \\
\text { of body length, deterioration of nervous } \\
\text { and visual systems }\end{array}$ & [124] \\
\hline & PS & $\begin{array}{c}0.07 \mu \mathrm{m} \\
5.0 \mu \mathrm{m} \\
20.0 \mu \mathrm{m}\end{array}$ & $\begin{array}{c}0.002,0.2 \text { and } 2.0 \mathrm{mg} / \mathrm{L} \\
-\end{array}$ & $\begin{array}{c}5.7 \times 10^{-4}, 1.25 \times 10^{-3} \text { and } \\
8.9 \times 10^{-4} \mathrm{mg} / \mathrm{mg} \text { fish }(5.0 \mu \mathrm{m} \\
\text { particles accumulated in gill, liver, } \\
\text { and gut, respectively })\end{array}$ & $\begin{array}{l}\text { accumulation of particles in fish gill, } \\
\text { gut, and liver, deterioration of liver } \\
\text { metabolism, oxidative stress }\end{array}$ & [125] \\
\hline $\begin{array}{c}\text { Cyprinus carpio } \\
\text { Carassius auratus } \\
\text { Hypophthalmichthys } \\
\text { molitrix } \\
\text { Pseudorasbora parva } \\
\text { Megalobrama } \\
\text { amblycephala } \\
\text { Hemiculter bleekeri }\end{array}$ & $49.1 \%$ cellophane & $76.3 \%$ particles $<5 \mathrm{~mm}$ & - & $\begin{array}{l}2.5 \pm 1.3 \text { particles } / \text { fish } \\
1.9 \pm 1.0 \text { particles } / \text { fish } \\
3.8 \pm 2.0 \text { particles } / \text { fish } \\
2.5 \pm 1.8 \text { particles } / \text { fish } \\
1.8 \pm 1.7 \text { particles } / \text { fish } \\
2.1 \pm 1.1 \text { particles } / \text { fish }\end{array}$ & accumulation in stomach and intestine & [126] \\
\hline $\begin{array}{c}\text { Bagre bagre } \\
\text { Bagre marinus } \\
\text { Caranx hippos } \\
\text { Lutjanus analis } \\
\text { Polydactylus oligodon } \\
\text { Cynoscion leiarchus } \\
\text { Sphyrna tiburo } \\
\text { Trichiurus lepturus }\end{array}$ & $\begin{array}{c}97.4 \% \text { of } \\
\text { polyamide }\end{array}$ & $0.38-4.16 \mathrm{~mm}$ & - & $\begin{array}{l}\text { 12.8 particles/fish } \\
\text { 7.8 particles/fish } \\
\text { 30.7 particles/fish } \\
\text { 1.0 particle/fish } \\
\text { 3.0 particles/fish } \\
\text { 2.0 particles/fish } \\
\text { 9.0 particles/fish } \\
\text { 2.0 particles/fish }\end{array}$ & accumulation in stomach and intestine & [127] \\
\hline
\end{tabular}

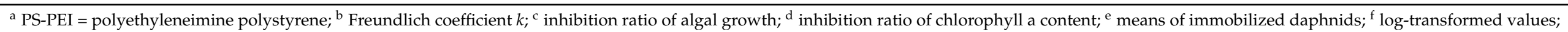
$\mathrm{g}$ survival percentages of zebrafish. 


\subsection{Ecotoxicological Effects on Vibrio fischeri}

The toxicological test using Vibrio fischeri ( $V$. fischeri) is considered simple, relatively fast, and cost-effective. Therefore, it is not surprising that, despite the fact that $V$. fischeri is a marine bacterium, this test is often applied for the ecotoxicological analysis of non-marine samples like wastewaters, freshwaters, leachates, etc. The test is based on measuring the intensity of blue-green luminescence light since $V$. fischeri has the ability to bioluminescence (associated with the presence of enzyme luciferase). Its wide applicability includes various tested subjects posing adverse effects to the water environment such as metals, antibiotics, herbicides, and other organic and inorganic compounds [128]. Yet, only a few authors used $V$. fischeri for the determination of MPs toxicological effects, presumably due to insufficient sensitivity [107]. However, Gagné [112] exposed $V$. fischeri to PE beads (1-3 $\mu \mathrm{m})$ at $1000 \mathrm{mg} / \mathrm{L}$ during 5 and $30 \mathrm{~min}$ observing bioluminescence decrease, with $\mathrm{EC}_{20}$ values of 3600 and $2600 \mathrm{mg} / \mathrm{L}$, respectively (Table 3). Moreover, Gambardella et al. [107] exposed V. fischeri to oxidized and not oxidized PE particles; size range of 1-500 $\mu \mathrm{m}$ and concentration range of $0.625-10 \mathrm{mg} / \mathrm{L}$. According to the results after $30 \mathrm{~min}$ exposure, PE particles are not toxic to $V$. fischeri at environmentally relevant concentrations or at even higher concentrations. Besides, the investigated particle sizes did not affect $V$. fischeri, presumably due to the fact that the cell wall acted as a barrier for particles of the used size range [107]. However, although not studied, authors assumed that smaller particles than studied might cause a toxic effect. Issues of $V$. fischeri for determining MPs toxicity can be associated with the following facts: (i) MPs are solids, thus, may interfere with measuring bioluminescence, and (ii) exposing time (15 min according to ISO 11348-3) is quite short to determine actual MPs effects. MPs may be dissolved in an appropriate solvent, however, solvent interference with toxic effect has to be accounted for as well. Another approach is to use it in the determining toxic effects of MPs constituents (monomers, additives), which may leach during partial MPs degradation; however, filtration prior test to remove solid MPs should be applied.

\subsection{Ecotoxicological Effects on Algae}

Algae (especially phytoplankton) are the primary producers and basis of the aquatic food chain. Therefore, any adverse effect on algae affects the entire ecosystem [115], as presented in Figure 4.

Various adverse effects of MPs on algae have been reported already; mostly enlightening negative influence on algae growth. Wu et al. [116] reported that PP and PVC MPs at concentrations of 5, 10,50,100, 250, and $500 \mathrm{mg} / \mathrm{L}$ showed a negative effect on chlorophyll of freshwater algae Chlorella pyrenoidosa and Microcystis flos-aquae. According to the inhibition values recorded, $\mathrm{PVC}$ is more toxic in the water environment in comparison to PP. MPs can decrease photosynthesis efficiency due to adsorption on algae surface [114] or by reducing the chlorophyll level in cells [116] (Table 3). MPs adsorption on algae surface hinders the exchange of nutrients, gasses, and toxic metabolites. Mao et al. [115] reported that PS particles in size range between 0.1 and $1.0 \mu \mathrm{m}$ and at concentrations 10,50 , and $100 \mathrm{mg} / \mathrm{L}$ induced the inhibition of algal growth (higher effect with smaller particles, Table 3), oxidative stress and caused morphological changes on freshwater algae Chlorella pyrenoidosa cell. Morphological changes of the algal cell are commonly related to the occurrence of hetero-aggregation between MPs, yielding structures larger and heavier than common MPs, resulting eventually in physical damage of cell [129]. Such particles can reach easier deeper layers of water, thus, hetero-aggregation supports MPs transfer to the bottom of aquatic ecosystems [115]. Recent studies have focused mainly on marine algae. Therefore, it is necessary to conduct studies on freshwater algae that are present in lakes, rivers, and streams to close the knowledge gap in ecotoxicological MPs assessment in freshwater sources. The environmental characteristics of sources have to be considered as well; such factors may determine relevant direct and indirect effects on algal communities, consequently affecting specific ecotoxicological responses. 


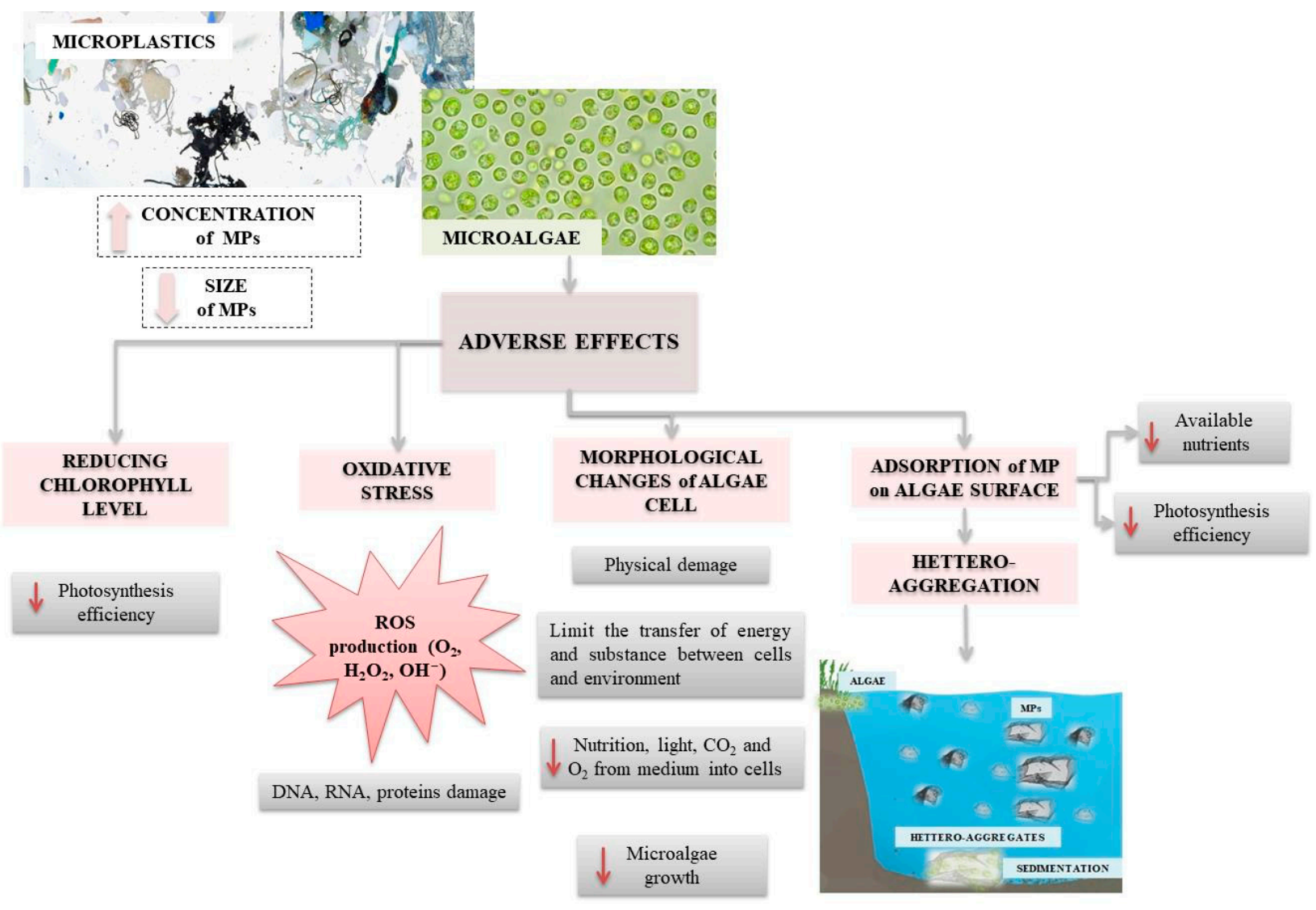

Figure 4. Effects of microplastics on microalgae.

\subsection{Ecotoxicological Effects on Daphnids}

Daphnia, a genus of planktonic freshwater crustaceans, are frequently used in ecotoxicological laboratory tests, especially Daphnia magna (D. magna) [121,130-132]. Studies indicate that ingestion depends on MPs size, shape, type, and concentration [121,130]. Thus, D. magna can ingest PE particles in the range 63-75 $\mu \mathrm{m}$ [130] and PET long fibers $<1400 \mu \mathrm{m}$ [121]. MPs agglomeration, occurring at higher MPs concentrations, would yield a lowering of ingestion rate [108,121,131,132]. Krogh Frydkjær et al. [108] reported that elevated concentrations of PE particles decreased mobility of D. magna, while irregular shaped fragments $(10-75 \mu \mathrm{m})$ affected $D$. magna more intensively than regular shaped beads $(10-106 \mu \mathrm{m})$. Rehse et al. [119] observed size-dependent differences in inhibitory effects; smaller PE particles are more toxic for D. magna than larger ones. Analogous results were obtained for exposing $D$. magna to PS [131]. It seems that smaller MPs affect $D$. magna by adhering to inner and outer surfaces, impairing filtering activity, compromising gut integrity, and entering tissue and cells [107]. Besides ingestion, MPs influenced the egestion of D. magna as well. The egestion is a very important function for organisms; very low egestion (or even the total absence) leads to reducing food intake and consequently starving $[105,121]$. It has been reported that $D$. magna egests regular-shaped PE at a higher rate than irregular ones, indicating that spiky particles retained longer in the organism, and have a higher hazard effect $[108,130]$. This is quite concerning because irregular MPs are commonly present in aquatic ecosystems [108]. Jaikumar et al. [120] exposed D. magna, Daphnia pulex, and Ceriodaphnia dubia to MPs at various temperatures and discovered that sensitivity to various MPs may differ between species, while the acute sensitivity of Daphnia sharply increases with the temperature. Jemec et al. [121] tested the potential effect of pre-feeding Daphnia by algae (simulating real environmental conditions) and found that pre-feeding did not affect MPs uptake on daphnids growth, but had a significant influence 
on their mortality (pre-fed daphnids showed no increase of mortality). Besseling et al. [133] found that tiny PS particles have a negative influence on daphnids body size and reproduction: $67.7 \%$ of malformed offspring were observed. It is important to note that in all the above-mentioned daphnids studies, MPs concentrations were generally much higher than the environmental ones.

\subsection{Ecotoxicological Effects on Fish}

MPs were detected in the intestine of fish caught in freshwater (urban areas [134], WWTPs down-streams [135]) and oceans (both: pelagic and demersal fish) [109]. PE, nylon, and polyamide $[109,136]$ were emphasized as the most abundant polymers. Exposure to MPs might have severe hazardous effects on fish including neurotoxicity [137], the reduction of predatory performance, growth, and reproduction [106], oxidative stress, and mortality [110]. Higher MPs concentration influenced mortality and length of larval fish in the case of European perch Perca fluviatilis [138]. Medaka fish Oryzias latipes was dietary exposed to the virgin and marine PE $(<0.5 \mathrm{~mm})$; the results showed bioaccumulation, liver stress, and even tumor formation [139]. Oryzias latipes embryos were also exposed to MPs with different CECs adsorbed (polycyclic aromatic hydrocarbons, polychlorinated biphenyls, polybrominated diphenyl ethers); MPs contributed to the transportation of CECs to embryos, negatively affecting juvenile growth and survival rate. MPs biomagnifications potential was studied as well $[76,140]$. Once ingested, MPs come to the gastrointestinal tract; MPs $<150 \mu \mathrm{m}$ can pass through gut epithelium (i.e., it can penetrate into the organism), while those $<1.5 \mu \mathrm{m}$ can penetrate into organs. Yet, most MPs remain in the gastrointestinal tract. MPs ingestion can lead to increased biomagnification of MPs (and other contaminants, if adsorbed) in the food chains as toxins leach into tissue once present in the organism. Fish growth stage was correlated with the sensitivity to MPs exposure; results showed that embryos are much more sensitive than adults [106,138]. Jabeen et al. [126] investigated the presence of MPs in several freshwater species of fish (listed in Table 3); in $95.7 \%$ of subjected freshwater fish, MPs were found. The most abundant shape belonged to fibers, while cellophane followed by PET and polyester were the most abundant types. The most abundant shape of MPs found in the fishes from the Río de la Plata also belonged to fibers (even 96\%). The highest abundance of MP particles was found in the gut of fishes caught near sewage discharge as a sampling site [141]. On the other hand, the most abundant MPs shape found in fishes from the Amazon River estuary (97.4\%) was detected as pellets and mostly pertained to polyamide [127]. Most of these MPs are found in stomachs $(92.1 \%)$, while the rest was in the intestines. The ingestion of polyamide MP pellets is not surprising due to the high density of polyamide $\left(1.13-1.15 \mathrm{~g} / \mathrm{m}^{3}\right)$ and the round shape of pellets, highly contributing to MPs accessibility to fishes.

One of the freshwater organisms often used in ecotoxicological studies is zebrafish Danio rerio (D. rerio). It has been proven that MPs can cause morphological deformations of D. rerio [125], as well as the changes of nervous (acetylcholinesterase activity, AChE), visual [124] and immune system [142], oxidative stress (Reactive Oxygen Species-ROS) [125], reproductive toxicity [143], and damage of intestine [123], as shown in Figure 5.

Lu et al. [125] studied MPs (PS) accumulation in the adult $D$. rerio over 7 days; $5 \mu \mathrm{m}$ particles were detected in gill, liver, and gut, while $20 \mu \mathrm{m}$ particles were not found in liver. Zhao et al. [144] exposed only male adult zebrafish to $5 \mu \mathrm{m}$ PS over 21 days and found a significant decrease of weight, influencing zebrafish condition and growth. Disruption of hepatic metabolism was noticed as well. Chen et al. [124] exposed zebrafish larvae to micro- and nano-sized PS and found 22\% inhibition of locomotor activity, including body length reduction for $6 \%$, as well as neurotoxicity and genotoxicity. Lee et al. [145] tested adverse effects of PS (50, 200, and $500 \mathrm{~nm}$ ) on zebrafish's embryos; $50 \mathrm{~nm}$ particles passed through pores of chorion and penetrated into the body and were accumulated in tissues (brain, retina, blood vessels) and yolk. Parenti et al. [146] detected penetration of larger particles $(500 \mathrm{~nm}$ ) in embryo's tissues. Lei et al. [123] exposed D. rerio to various MPs types in concentrations $0.001-10.0 \mathrm{mg} / \mathrm{L}$ over 10 days. The obtained results showed: (i) very low 
mortality for PE, PP, PS, PVC, and polyamide ( $0,27,0,17$, and $2 \%$, respectively), and (ii) that $70 \mu \mathrm{m}$ particles of $\mathrm{PE}, \mathrm{PP}, \mathrm{PVC}$, and polyamide caused intestine damage, while no changes in morphology were observed with PS $(0.1,1.0$, and $5.0 \mu \mathrm{m}$ particles).

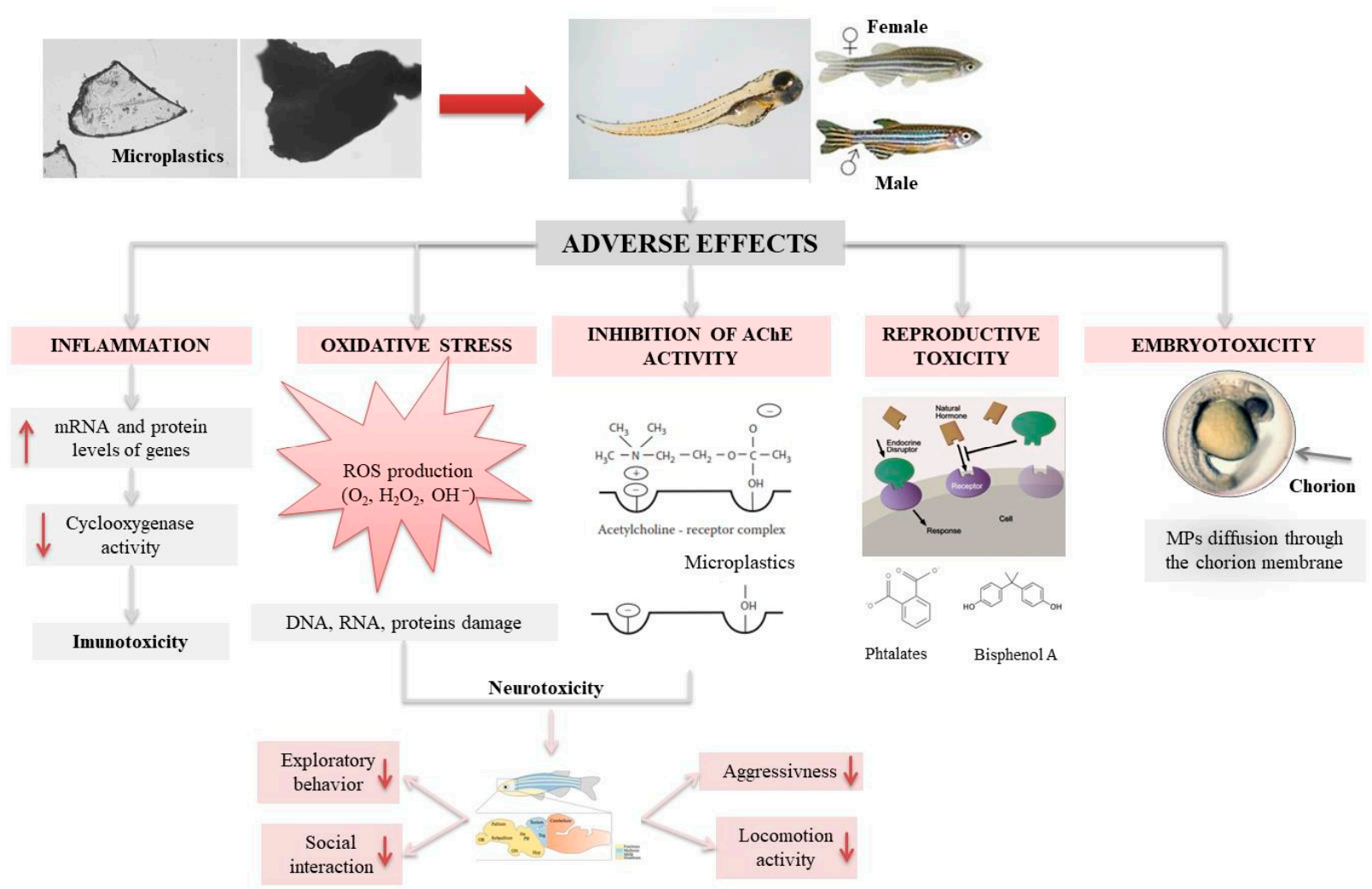

Figure 5. Effects of microplastics on zebrafish.

Determining the toxicity of MPs is anything but simple. As mentioned, MPs are in a solid state, which may raise some difficulties in determining ecotoxicity in a laboratorysimulated environment. For example, MPs can settle to the bottom or stick to the walls of wells or float to the surface (depending on their density). In such a case, the zebra embryos are not exposed to MPs, and the most important is the exposure in the water column. Furthermore, if mixing is applied to prevent deposition, a sufficient number of revolutions cannot be achieved without consequences for the zebrafish population. Accordingly, it can be assumed that the toxicity of MPs is much easier to determine in adults having the ability to swallow MPs than in embryos. However, the embryo toxicity test is more sensitive to pollution and is ethically acceptable (in vitro). Therefore, further research is needed to adjust conditions for toxicity tests on zebrafish embryos.

\subsection{Cumulative Effects of MPs and Anthropogenic Molecules}

MPs released in the environment are exposed to other hazardous substances (e.g., heavy metals, CECs) and can act as vectors for their further transfer. MPs have strong adsorption capacity due to small particle size, large specific surface area, and high hydrophobicity $[147,148]$. PE, PP, PS, and PVC particles showed high sorption potential for hexachlorocyclohexanes, polycyclic aromatic hydrocarbons, chlorinated benzenes, and other CECs [149]. MPs sorption capacity depends on physical-chemical characteristics, composition, color, shape, and size [54]; e.g., colorless MPs showed greater adsorption potential for polychlorinated biphenyls (PCBs) comparing to colored ones [150].

The ingestion of MPs with hazardous substances adsorbed can have various adverse effects on organisms since multiple modes of action can occur. The combined toxicity effect (synergism) of MPs and adsorbed substances [131,151,152] must not be excluded 
from consideration as well. The most studied anthropogenic molecules adsorbed on MPs include heavy metals and CECs. It was found that PS with cadmium adsorbed exhibited increased toxicity to $D$. rerio. Thus, MPs contributed to the accumulation of cadmium in fish livers, guts, and gills, and caused oxidative stress and inflammation [153]. In the case of $17 \alpha$-ethinylestradiol (EE2) adsorbed, genotoxicity, reproductive and behavioral effects were observed [124]. Luís et al. [154] studied the synergistic action in adverse effects of simultaneous exposure of early juveniles of goby fish (Pomatoschistus microps) to PE microspheres and chromium(VI). A significant decrease of predatory performance $(\leq 67 \%)$ and the inhibition of $\mathrm{AChE}(\leq 31 \%)$ were noticed, which was not observed when species were exposed to each pollutant separately. Endocrine disruptors are often used in studying potentially combined effects with MPs. Besseling et al. [155] studied adverse effects of PS with PCBs adsorbed on lugworm Arenicola marina; however, they concluded that PS does not act as a vector for PCBs, as demonstrated for cadmium [153] or 17 $\alpha$-ethinylestradiol [124]. A similar conclusion was given by Devriese et al. [156] who tested the influence of PS and PE microspheres with adsorbed PCBs on Norway lobsters (Nephrops norvegicus) and found no significant increase in PCBs bioaccumulation. Zhang et al. [118] examined the behavior of $D$. magna exposed to 1 and $10 \mu \mathrm{m}$ PS, pharmaceutical roxithromycin, and their mixture, reporting the strongest biological response during simultaneous exposure.

It is interesting that reports related to MPs particles with pesticides adsorbed [151,157] are rather scarce despite the facts that: (i) many pesticides are considered as CECs and are included in the list of priority substances [158] and their watch list [159]; and (ii) the agriculture, which is among the major sources of MPs and pesticides in the environment $[160,161]$, makes that these two pollutant classes are commonly present in the environment.

MPs can also adsorb various microorganisms, including those able to degrade MPs, or, more concerning, pathogens. Once formed, surface biofilm can cause changes of surface properties (e.g., decreasing hydrophobicity), resulting in the increased MPs density, and consequently yielding MPs sinking to deeper layers of aquatic ecosystems, exposing a filtering organism to MPs intake as well [15]. This is particularly concerning for low-density MPs (e.g., PE ad PP) that mostly float.

\section{Conclusions}

The analysis of recent studies on MPs environmental presence including adverse effects based on their bioactivity was carried out, showing a growing interest of the scientific community for plastic pollution. Ecotoxicological studies investigated MPs impact on organisms, mostly aquatic including algae, Daphnia magna, and fish (mostly Danio rerio). Some of the reported results are contradictory, but toxic effects exist nonetheless, strongly depending on MPs size, shape, and type. It was proven that MPs may cause various adverse effects such as neurotoxicity, reproductive toxicity, oxidative stress, immunotoxicity, and a decrease in photosynthetic efficiency. Accordingly, it seems that the knowledge of MPs presence in the environment and related adverse effects is still relatively scarce. There is a growing need for extensive research to be carried out with different shapes, sizes, types, and colors of MPs, extending the variety of tested (micro)organisms to get a broader insight into this emerging environmental issue. The role of MPs as vectors for other environmental pollutants, significantly increasing hazardous potential of MPs presence in (water) environment, is indicated, but more proofs on the occurring mechanisms need to be determined. Besides other environmental pollutants adsorbed, the risk of toxic effects may be increased by leaching of MPs constituents (e.g., additives, colorants, pigments) as well, requiring the combination of toxicological studies with powerful analytical techniques (e.g., spectroscopy- and chromatography-based methods) to identify their presence in the studied matrix and potential contribution to adverse effects established. Thus, further ecotoxicology investigations are needed to provide pieces of substantial information on mixture toxicity and interaction of MPs with other environmental toxicants, including also theoretical studies in order to decrease experimental costs and to respect ethical issues. Besides, it should be noted that the inconsistency in sample compositions (various matrices, 
diversities regarding MPs size and shape) and characterization procedures significantly complicated the comparison of reported results. Accordingly, the setting of standard procedures is highly necessary in order to obtained more detailed information.

Author Contributions: Conceptualization, H.K., D.K.G., and T.B.; writing-original draft preparation, M.M., D.K.G., Š.U., and M.C.; writing-review and editing, H.K., D.K.G., T.B., V.O.B., Š.U., and D.D.D. All authors have read and agreed to the published version of the manuscript.

Funding: This research was funded by Croatian Science Foundation, grant number IP-2019-04-9661. And The APC was funded by IP-2019-04-9661.

Institutional Review Board Statement: Not applicable.

Acknowledgments: The authors would like to acknowledge the financial support of the Croatian Science Foundation, project Advanced Water Treatment Technologies for Microplastics Removal (AdWaTMiR) (IP-2019-04-9661). D.D.D. also acknowledges support from the University of Cincinnati through the Herman Schneider Professorship in the College of Engineering and Applied Sciences.

Conflicts of Interest: The authors declare no conflict of interest.

\section{References}

1. Chalmin, P. The history of plastics: From the capitol to the Tarpeian Rock. Field Actions Sci. Rep. 2019, 19, 6-11.

2. PlasticsEurope, Plastics-the Facts 2019. An analysis of European plastics production, demand and waste data. Available online: https:/ / www.plasticseurope.org/application/files/9715/7129/9584/FINAL_web_version_Plastics_the_facts2019_14 102019.pdf (accessed on 25 October 2020).

3. Rodrigues, M.O.; Gonçalves, A.M.M.; Gonçalves, F.J.M.; Nogueira, H.; Marques, J.C.; Abrantes, N. Effectiveness of a methodology of microplastics isolation for environmental monitoring in freshwater systems. Ecol. Indic. 2017, 89, 488-495. [CrossRef]

4. Akdogan, Z.; Guven, B. Microplastics in the Environment: A critical review of current understanding and identification of future research needs. Environ. Pollut. 2019, 254, 1-24. [CrossRef] [PubMed]

5. Lu, L.; Luo, T.; Zhao, Y.; Cai, C.; Fu, Z.; Jin, Y. Interaction between microplastics and microorganism as well as gut microbiota: A consideration on environmental animal and human health. Sci. Total Environ. 2019, 667, 94-100. [CrossRef]

6. Bond, T.; Ferrandiz-Mas, V.; Felipe-Sotelo, M.; van Sebille, E. The occurrence and degradation of aquatic plastic litter based on polymer physicochemical properties: A review. Crit. Rev. Environ. Sci. Technol. 2018, 48, 685-722. [CrossRef]

7. Gong, J.; Kong, T.; Li, Y.; Li, Q.; Li, Z.; Zhang, J. Biodegradation of microplastic derived from poly(ethylene terephthalate) with bacterial whole-cell biocatalysts. Polymers 2018, 10, 1326. [CrossRef]

8. Harrison, J.P.; Sapp, M.; Schratzberger, M.; Mark Osborn, A. Interactions between microorganisms and marine micro plastics: A call for research. Mar. Technol. Soc. J. 2011, 45, 12-20. [CrossRef]

9. Lambert, S.; Wagner, M. Microplastics are Contaminants of Emerging Concern in Freshwater Environments: An Overview; Wagner, M., Lambert, S., Eds.; Freshwater Microplastics; Springer Open: Cham, Switzerland, 2018; pp. 1-24.

10. Auta, H.S.; Emenike, C.U.; Fauziah, S.H. Distribution and importance of microplastics in the marine environment: A review of the sources, fate, effects, and potential solutions. Environ. Int. 2017, 102, 165-176. [CrossRef]

11. Gajšt, T.; Bizjak, T.; Palatinus, A.; Liubartseva, S.; Kržan, A. Sea surface microplastics in Slovenian part of the Northern Adriatic. Mar. Pollut. Bull. 2016, 113, 392-399. [CrossRef]

12. Jiang, J.Q. Occurrence of microplastics and its pollution in the environment: A review. Sustain. Prod. Consum. 2018, 13, 16-23. [CrossRef]

13. Wright, S.L.; Thompson, R.C.; Galloway, T.S. The physical impacts of microplastics on marine organisms: A review. Environ. Pollut. 2013, 178, 483-492. [CrossRef]

14. Horton, A.A.; Walton, A.; Spurgeon, D.J.; Lahive, E.; Svendsen, C. Microplastics in freshwater and terrestrial environments: Evaluating the current understanding to identify the knowledge gaps and future research priorities. Sci. Total Environ. 2017, 586, 127-141. [CrossRef]

15. Li, J.; Liu, H.; Paul Chen, J. Microplastics in freshwater systems: A review on occurrence, environmental effects, and methods for microplastics detection. Water Res. 2018, 137, 362-374. [CrossRef] [PubMed]

16. Bergmann, M.; Wirzberger, V.; Krumpen, T.; Lorenz, C.; Primpke, S.; Tekman, M.B.; Gerdts, G. High Quantities of Microplastic in Arctic Deep-Sea Sediments from the HAUSGARTEN Observatory. Environ. Sci. Technol. 2017, 51, 11000-11010. [CrossRef] [PubMed]

17. He, D.; Luo, Y.; Lu, S.; Liu, M.; Song, Y.; Lei, L. Microplastics in soils: Analytical methods, pollution characteristics and ecological risks. TrAC-Trends Anal. Chem. 2018, 109, 163-172. [CrossRef]

18. Shan, J.; Zhao, J.; Liu, L.; Zhang, Y.; Wang, X.; Wu, F. A novel way to rapidly monitor microplastics in soil by hyperspectral imaging technology and chemometrics. Environ. Pollut. 2018, 238, 121-129. [CrossRef] [PubMed]

19. Birch, Q.T.; Potter, P.M.; Pinto, P.X.; Dionysiou, D.D.; Al-Abed, S.R. Sources, transport, measurement and impact of nano and microplastics in urban watersheds. Rev. Environ. Sci. Biotechnol. 2020, 19, 275-336. [CrossRef] [PubMed] 
20. Wright, S.L.; Ulke, J.; Fonta, A.; Chan, K.L.A.; Kelly, F.J. Atmospheric microplastic deposition in an urban environment and an evaluation of transport. Environ. Int. 2020, 136, 105411. [CrossRef]

21. Boucher, J.; Friot, D. Primary Microplastics in the Oceans: A Global Evaluation of Sources; IUCN: Gland, Switzerland, 2017.

22. de Sá, L.C.; Oliveira, M.; Ribeiro, F.; Rochad, T.L.; Futtera, M.N. Studies of the effects of microplastics on aquatic organisms: What do we know and where should we focus our efforts in the future? Sci. Total Environ. 2018, 645, 1029-1039. [CrossRef]

23. Ding, J.; Zhang, S.; Zou, H.; Zhang, Y.; Zhu, R. Occurrence, source and ecotoxicological effect of microplastics in freshwater environment. Ecol. Environ. Sci. 2017, 26, 1619-1626.

24. Naji, A.; Nuri, M.; Vethaak, A.D. Microplastics contamination in molluscs from the northern part of the Persian Gulf. Environ. Pollut. 2018, 235, 113-120. [CrossRef] [PubMed]

25. Liebezeit, G.; Liebezeit, E. Non-pollen particulates in honey and sugar. Food Addit. Contam. Part A Chem. Anal. Control Expo. Risk Assess. 2013, 30, 2136-2140. [CrossRef] [PubMed]

26. Yang, D.; Shi, H.; Li, L.; Li, J.; Jabeen, K.; Kolandhasamy, P. Microplastic pollution in table salts from China. Environ. Sci. Technol. 2015, 49, 13622-13627. [CrossRef]

27. Liebezeit, G.; Liebezeit, E. Synthetic particles as contaminants in German beers. Food Addit. Contam. Part A Chem. Anal. Control Expo. Risk Assess. 2014, 31, 1574-1578. [CrossRef] [PubMed]

28. Schymanski, D.; Goldbeck, C.; Humpf, H.U.; Fürst, P. Analysis of microplastics in water by micro-Raman spectroscopy: Release of plastic particles from different packaging into mineral water. Water Res. 2018, 129, 154-162. [CrossRef]

29. de Souza Machado, A.A.; Kloas, W.; Zarfl, C.; Hempel, S.; Rillig, M.C. Microplastics as an emerging threat to terrestrial ecosystems Glob. Chang. Biol. 2018, 24, 1405-1416. [CrossRef]

30. Zhu, L.; Bai, H.; Chen, B.; Sun, X.; Qu, K.; Xia, B. Microplastic pollution in North Yellow Sea, China: Observations on occurrence, distribution and identification. Sci. Total Environ. 2018, 636, 20-29. [CrossRef]

31. EUROPEAN CHEMICALS AGENCY(ECHA). Available online: https://echa.europa.eu/documents/10162/12414bc7-6bb2-17e7 -c9ec-652a20fa43fc (accessed on 27 October 2020).

32. D'Ambrières, W. Plastics recycling worldwide: Current overview and desirable changes. Field Actions Sci. Rep. $2019,19,12-21$.

33. EC. European Strategy for Plastics in a Circular Economy. COM 2018, 28. Available online: https://ec.europa.eu/environment/ circular-economy / pdf/plastics-strategy.pdf (accessed on 22 December 2020).

34. Gutiérrez, C.; de Haro, J.C.; García, M.T.; Gracia, I.; de Lucas, A.; Rodríguez, J.F. Polystyrene Wastes: Threat or Opportunity? In Environment, Energy and Climate Change I: Environmental Chemistry of Pollutants and Wastes; Jiménez, E., Cabañas, B., Lefebvre, G., Eds.; Springer: Berlin/Heidelberg, Germany, 2015; pp. 261-286.

35. Rezania, S.; Park, J.; Din, M.F.M.; Taib, S.M.; Talaiekhozani, A.; Yadav, K.K.; Kamyab, H. Microplastics pollution in different aquatic environments and biota: A review of recent studies. Mar. Pollut. Bull. 2018, 133, 191-208. [CrossRef]

36. Teck Kim, Y.; Min, B.; Won Kim, K. General characteristics of packaging materials for food system. In Innovations in Food Packaging; Han, J.H., Ed.; Academic Press: London, UK, 2014; pp. 13-35.

37. Glaser, J.A. Biological degradation of polymers in the environment. In Plastics in the Environment; Gomiero, A., Ed.; IntechOpen: London, UK, 2019.

38. McLain, V.C. Final report on the safety assessment of polyethylene. Int. J. Toxicol. 2007, 26, 115-127.

39. Summers, J.W. The melting temperature (or not melting) of poly(vinyl chloride). J. Vinyl. Addit. Techn. 2008, 14, 105-109. [CrossRef]

40. Görtz, H.H. Polystyrene: Syndiotactic. In Encyclopedia of Materials: Science and Technology; Jürgen Buschow, K.H., Cahn, R.W., Flemings, M.C., Ilschner, B., Kramer, E.J., Mahajan, S., Veyssière, P., Eds.; Elsevier: Amsterdam, The Netherlands, 2001; pp. $7742-7744$.

41. Beyler, C.L.; Hirschler, M.M. Thermal decomposition of polymers. In SFPE Handbook of Fire Protection Engineering, 4th ed.; DiNenno, P.J., Ed.; National Fire Protection Association: Quincy, MA, USA, 2002; pp. 112-143.

42. Ehrenstein, G.W. Polymeric Materials: Structure, Properties, Applications; Hanser Gardner Publications: München, Germany, 2012.

43. Hrnjak-Murgić, Z.; Rešček, A.; Ptiček Siročić, A.; Kratofil Krehula Lj Katančić, Z. Nanoparticles in Active Polymer Food Packaing; Smithers Pira: Surrey, UK, 2015.

44. Sangeetha Devi, R.; Rajesh Kannan, V.; Natarajan, K.; Nivas, D.; Kannan, K.; Chandru, S.; Robert Anthony, A. The Role of Microbes in Plastic Degradation, in R. Chandra: Environmental Waste Management; CRC Press: Boca Raton, FL, USA, 2015; pp. 341-370.

45. Dutta Laha, S.; Dutta, K.; Paban Kundu, P. Biodegradation of low density polyethylene films. In Handbook of Research on Microbial Tools for Environmental Waste Management; Pathak, V.M., Navneet, Eds.; IGI Global: Hershey, PA, USA, 2018 ; pp. $282-318$.

46. Krueger, M.C.; Harms, H.; Schlosser, D. Prospects for microbiological solutions to environmental pollution with plastics. Appl. Microbiol. Biotechnol. 2015, 99, 8857-8874. [CrossRef] [PubMed]

47. Arutchelvi, J.; Sudhakar, M.; Arkatkar, A.; Doble, M.; Bhaduri, S.; Uppara, P.V. Biodegradation of polyethylene and polypropylene. Indian J. Biotechnol. 2008, 7, 9-22.

48. Artham, T.; Doble, M. Biodegradation of aliphatic and aromatic polycarbonates. Macromol. Biosci. 2008, 8, 14-24. [CrossRef]

49. Vasile, C. Degradation and decomposition. In Handbook of Polyolefins Synthesis and Properties; Vasile, C., Seymour, R.B., Eds.; Marcel Dekker Inc: New York, NY, USA, 1993; pp. 479-506.

50. Ho, B.T.; Roberts, T.K.; Lucas, S. An overview on biodegradation of polystyrene and modified polystyrene: The microbial approach. Crit. Rev. Biotechnol. 2018, 38, 308-320. [CrossRef] 
51. Mor, R.; Sivan, A. Biofilm formation and partial biodegradation of polystyrene by the actinomycete Rhodococcus ruber: Biodegradation of polystyrene. Biodegradation 2008, 19, 851-858. [CrossRef]

52. Webb, H.K.; Arnott, J.; Crawford, R.J.; Ivanova, E.P. Plastic degradation and its environmental implications with special reference to poly (ethylene terephthalate). Polymers 2013, 5, 1-18. [CrossRef]

53. Müller, R.J.; Schrader, H.; Profe, J.; Dresler, K.; Deckwer, W.D. Enzymatic degradation of poly(ethylene terephthalate): Rapid hydrolyse using a hydrolase from T. Fusca. Macromol. Rapid Commun. 2005, 26, 1400-1405. [CrossRef]

54. Prokić, M.D.; Radovanović, T.B.; Gavrić, J.P.; Faggio, C. Ecotoxicological effects of microplastics: Examination of biomarkers, current state and future perspectives. TrAC-Trend. Anal. Chem. 2019, 111, 37-46. [CrossRef]

55. Murphy, F.; Ewins, C.; Carbonnier, F.; Quinn, B. Wastewater treatment works (WwTW) as a source of microplastics in the aquatic environment. Environ. Sci. Technol. 2016, 50, 5800-5808. [CrossRef] [PubMed]

56. Wu, P.; Huang, J.; Zheng, Y.; Yang, Y.; Zhang, Y.; He, F.; Chen, H.; Quan, G.; Yan, J.; Li, T.; et al. Environmental occurrences, fate and impacts of microplastics. Ecotoxicol. Environ. Saf. 2019, 184, 1-16. [CrossRef]

57. Nizzetto, L.; Futter, M.; Langaas, S. Are agricultural soils dumps for microplastics of urban origin? Environ. Sci. Technol. 2016, 50, 10777-10779. [CrossRef] [PubMed]

58. Do, T.C.V.; Scherer, H.W. Compost and biogas residues as basic materials for potting substrates. Plant. Soil. Environ. 2012, 58, 459-464. [CrossRef]

59. Duis, K.; Coors, A. Microplastics in the aquatic and terrestrial environment: Sources (with a specific focus on personal care products), fate and effects. Environ. Sci. Eur. 2016, 28, 1-25. [CrossRef] [PubMed]

60. Lambert, S.; Sinclair, C.J.; Boxall, A.B. Occurrence, degradation and effect of polymer-based materials in the environment. Rev. Environ. Contamin. Toxicol. 2014, 227, 1-53.

61. Elert, A.M.; Becker, R.; Duemichen, E.; Eisentraut, P.; Falkenhhagen, J.; Sturm, H.; Braun, U. Comparison of different methods for MP detection: What can we learn from them, and why asking the right question before measurements matters? Environ. Pollut. 2017, 231, 1256-1264. [CrossRef]

62. Industrievereinigung Chemiefaser e.V (2015) Production since 1975. Available online: https:/ /www.ivc-ev.de/live/index.php? page_id=87 (accessed on 30 October 2020).

63. Browne, M.A.; Crump, P.; Niven, S.J.; Teuten, E.; Tonkin, A.; Galloway, T.; Thompson, R. Accumulation of microplastic on shorelines worldwide: Sources and sinks. Environ. Sci. Technol. 2011, 45, 9175-9179. [CrossRef]

64. Mateo-Sagasta, J.; Raschid-Sally, L.; Thebo, A. Global wastewater and sludge production: Treatment and use. In Wastewater: Economic Asset in an Urbanizing World; Drechsel, P., Qadir, M., Wichelns, D., Eds.; Springer: Dordrecht, The Netherlands, 2015; pp. 15-38.

65. Raju, S.; Carbery, M.; Kuttykattil, A.; Senathirajah, K.; Subashchandrabose, S.R.; Evans, G.; Thavamani, P. Transport and fate of microplastics in wastewater treatment plants: Implications to environmental health. Rev. Environ. Sci. Biotechnol. 2018, 17, 637-653. [CrossRef]

66. EU. Council Directive of 21 May 1991 concerning urban waste water treatment (91/271/EEC). Off. J. Eur. Communities L135 1991, 40-91.

67. Napper, I.E.; Bakir, A.; Rowland, S.J.; Thompson, R.C. Characterisation, quantity and sorptive properties of microplastics extracted from cosmetics. Mar. Pollut. Bull. 2015, 99, 178-185. [CrossRef] [PubMed]

68. Antunes, J.C.; Frias, J.G.L.; Micaelo, A.C.; Sobral, P. Resin pellets from beaches of the Portuguese coast and adsorbed persistent organic pollutants. Estuar. Coast. Shelf. Sci. 2013, 130, 62-69. [CrossRef]

69. Imhof, H.K.; Laforsch, C.; Wiesheu, A.C.; Schmid, J.; Anger, P.M.; Niessner, R.; Ivleva, N.P. Pigments and plastic in limnetic ecosystems: A qualitative and quantitative study on microparticles of different size classes. Water Res. 2011, 98, 64-74. [CrossRef] [PubMed]

70. Long, M.; Moriceau, B.; Gallinari, M.; Lambert, C.; Huvet, A.; Raffray, J.; Soudant, P. Interactions between microplastics and phytoplankton aggregates: Impact on their respective fates. Mar. Chem. 2015, 175, 39-46. [CrossRef]

71. Ivleva, N.; Wiesheu, A.C.; Niessner, R. Microplastic in Aquatic Ecosystems. Angew. Chem. Int. Ed. 2017, 56, 1720-1739. [CrossRef] [PubMed]

72. Desforges, J.-P.W.; Galbraith, M.; Ross, P.S. Ingestion of Microplastics by Zooplankton in the Northeast Pacific Ocean. Arch. Environ. Contam. Toxicol. 2015, 69, 320-330. [CrossRef]

73. Cole, M.; Lindeque, P.; Halsband, C.; Galloway, T.S. Microplastics as contaminants in the marine environment: A review. Mar. Pollut. Bull. 2011, 62, 2588-2597. [CrossRef]

74. Kooi, M.; Besseling, E.; Kroeze, C.; van Wezel, A.P.; Koelmans, A.A. Modeling the Fate and Transport of Plastic Debris in Fresh-waters: Review and Guidance. In Freshwater Microplastics: Emerging Environmental Contaminants; Wagner, S.M., Ed.; Lambert Springer Open: Cham, Switzerland, 2018; pp. 125-152.

75. EFSA CONTAM Panel (EFSA Panel on Contaminants in the Food Chain). Statement on the presence of microplastics and nano-plastics in food, with particular focus on seafood. EFSA J. 2016, 14, 4501.

76. Silva, A.B.; Bastos, A.S.; Justino, C.I.L.; da Costa, J.P.; Duarte, A.C.; Rocha-Santos, T.A.P. Microplastics in the environment: Chal-lenges in analytical chemistry-A review. Anal. Chim. Acta 2018, 1017, 1-19. [CrossRef]

77. Qiu, Q.; Tan, Z.; Wang, J.; Peng, J.; Li, M.; Zhan, Z. Extraction, enumeration and identification methods for monitoring microplastics in the environment. Estuarine Coast. Shelf Sci. 2016, 176, 102-109. [CrossRef] 
78. Lee, J.; Hong, S.; Song, Y.K.; Hong, S.H.; Jang, Y.C.; Jang, M.; Heo, N.W.; Han, G.M.; Lee, M.J.; Kang, D.; et al. Relationships among the abundances of plastic debris in different size classes on beaches in South Korea. Mar. Pollut. Bull. 2013, 77, 349-354. [CrossRef] [PubMed]

79. Sierra, I.; Chialanza, M.R.; Faccio, R.; Carrizo, D.; Fornaro, L.; Pérez-Parada, A. Identification of microplastics in wastewater samples by means of polarized light optical microscopy. Environ. Sci. Pollut. Res. 2019, 27, 7409-7419. [CrossRef] [PubMed]

80. Hidalgo-Ruz, V.; Gutow, L.; Thompson, R.C.; Thiel, M. Microplastics in the Marine Environment: A Review of the Methods Used for Identification and Quantification. Environ. Sci. Technol. 2012, 46, 3060-3075. [CrossRef] [PubMed]

81. Zhu, J.; Wang, C. Recent advance in the analysis methodologies for microplastics in aquatic organisms: Current knowledge and research challenges. Anal. Methods 2020, 12, 1-37. [CrossRef]

82. Klein, S.; Dimzon, I.K.; Eubeler, J.; Knepper, T.P. Analysis, Occurrence, and Degradation of Microplastics in the Aqueous Envi-ronment. In Freshwater Microplastics: Emerging Environmental Contaminants; Wagner, M., Lambert, S., Eds.; Springer Open: Cham, Switzerland, 2018; pp. 51-68.

83. Girão, A.V.; Caputo, G.; Ferro, M. Application of Scanning Electron Microscopy-Energy Dispersive X-Ray Spectroscopy (SEMEDS). In Arsenic Speciation in Algae; Elsevier: Amsterdam, The Netherlands, 2017; Volume 75, pp. 153-168.

84. Mehdinia, A.; Dehbandi, R.; Hamzehpour, A.; Rahnama, R. Identification of microplastics in the sediments of southern coasts of the Caspian Sea, north of Iran. Environ. Pollut. 2020, 258, 113738. [CrossRef]

85. Bergmann, M.; Gutow, L.; Klages, M. Marine Anthropogenic Litter; Springer Open: Cham, Switzerland, 2009.

86. Araujo, C.F.; Nolasco, M.M.; Ribeiro, A.M.; Ribeiro-Claro, P.J. Identification of microplastics using Raman spectroscopy: Latest developments and future prospects. Water Res. 2018, 142, 426-440. [CrossRef]

87. PAPER WP53077, Guide to the identification of microplastics by FTIR and Raman spectroscopy, Thermofisher Scientific. 2018. Available online: https:/ / assets.thermofisher.com/TFS-Assets/MSD/Application-Notes/WP53077-microplastics-identificationftir-raman-guide.pdf (accessed on 2 November 2020).

88. Mohan, A.J.; Sekhar, V.C.; Bhaskar, T.; Nampoothiri, K.M. Microbial assisted High Impact Polystyrene (HIPS) degradation. Bioresour. Technol. 2016, 213, 204-207. [CrossRef]

89. Leslie, H.; Brandsma, S.H.; Van Velzen, M.; Vethaak, A. Microplastics en route: Field measurements in the Dutch river delta and Amsterdam canals, wastewater treatment plants, North Sea sediments and biota. Environ. Int. 2017, 101, 133-142. [CrossRef]

90. Jung, M.R.; Horgen, F.D.; Orski, S.V.; Rodriguez, V.C.; Beers, K.L.; Balazs, G.H.; Jones, T.T.; Work, T.M.; Brignac, K.C.; Royer, S.-J.; et al. Validation of ATR FT-IR to identify polymers of plastic marine debris, including those ingested by marine organisms. Mar. Pollut. Bull. 2018, 127, 704-716. [CrossRef]

91. Noda, I.; Dowrey, A.E.; Haynes, J.L.; Marcott, C. Group Frequency Assignments for Major Infrared Bands Observed in Common Synthetic Polymers. In Physical Properties of Polymers Handbook; Springer: Berlin/Heidelberg, Germany, 2007; pp. 395-406.

92. Gulmine, J.; Janissek, P.; Heise, H.; Akcelrud, L. Polyethylene characterization by FTIR. Polym. Test. 2002, 21, 557-563. [CrossRef]

93. Mecozzi, M.; Nisini, L. The differentiation of biodegradable and non-biodegradable polyethylene terephthalate (PET) samples by FTIR spectroscopy: A potential support for the structural differentiation of PET in environmental analysis. Infrared Phys. Technol. 2019, 101, 119-126. [CrossRef]

94. Käppler, A.; Fischer, M.; Scholz-Böttcher, B.M.; Oberbeckmann, S.; Labrenz, M.; Fischer, D.; Eichhorn, K.-J.; Voit, B. Comparison of $\mu$-ATR-FTIR spectroscopy and py-GCMS as identification tools for microplastic particles and fibers isolated from river sediments. Anal. Bioanal. Chem. 2018, 410, 5313-5327. [CrossRef] [PubMed]

95. Bart, J.C.J. Plastics Additives: Advanced Industrial Analysis; IOS Press: Amsterdam, The Netherlands, 2006.

96. Tagg, A.S.; Sapp, M.; Harrison, J.P.; Ojeda, J.J. Identification and Quantification of Microplastics in Wastewater Using Focal Plane Array-Based Reflectance Micro-FT-IR Imaging. Anal. Chem. 2015, 87, 6032-6040. [CrossRef] [PubMed]

97. Ribeiro-Claro, P.; Nolasco, M.M.; Araujo, C. Characterization of Microplastics by Raman Spectroscopy. In Comprehensive Analytical Chemistry; Elsevier: Amsterdam, The Netherlands, 2017; Volume 75, pp. 119-151.

98. Zada, L.; Leslie, H.A.; Vethaak, A.D.; Tinnevelt, G.; Janssen, J.; Boer, J.F.; de Ariese, F. Fast microplastics identification with stim-ulated Raman scattering microscopy. J. Raman Spectrosc. 2018, 49, 1136-1144. [CrossRef]

99. De Tender, C.A.; Devriese, L.I.; Haegeman, A.; Maes, S.; Ruttink, T.; Dawyndt, P. Bacterial Community Profiling of Plastic Litter in the Belgian Part of the North Sea. Environ. Sci. Technol. 2015, 49, 9629-9638. [CrossRef] [PubMed]

100. Xiong, X.; Zhang, K.; Chen, X.; Shi, H.; Luo, Z.; Wu, C. Sources and distribution of microplastics in China's largest inland lake-Qinghai Lake. Environ. Pollut. 2018, 235, 899-906. [CrossRef] [PubMed]

101. Zhang, C.; Huang, K.C.; Rajwa, B.; Li, J.; Yang, S.; Lin, H.; Liao, C.-S.; Eakins, G.; Kuang, S.; Patsekin, V.; et al. Stimulated Raman scattering flow cytometry for label-free single-particle analysis. Optica 2017, 4, 103-109. [CrossRef]

102. Ghosal, S.; Chen, M.; Wagner, J.; Wang, Z.M.; Wall, S. Molecular identification of polymers and anthropogenic particles extracted from oceanic water and fish stomach-A Raman micro-spectroscopy study. Environ. Pollut. 2018, 233, 1113-1124. [CrossRef]

103. Duemichen, E.; Eisentraut, P.; Celina, M.; Braun, U. Automated thermal extraction-desorption gas chromatography mass spectrometry: A multifunctional tool for comprehensive characterization of polymers and their degradation products. J. Chromatogr. A 2019, 1592, 133-142. [CrossRef]

104. Carr, S.A.; Liu, J.; Tesoro, A.G. Transport and fate of microplastic particles in wastewater treatment plants. Water Res. 2016, 91, 174-182. [CrossRef] 
105. Cole, M.; Lindeque, P.; Fileman, E.; Halsband, C.; Galloway, T.S. The Impact of Polystyrene Microplastics on Feeding, Function and Fecundity in the Marine CopepodCalanus helgolandicus. Environ. Sci. Technol. 2015, 49, 1130-1137. [CrossRef]

106. De Sá, L.C.; Luís, L.G.; Guilhermino, L. Effects of microplastics on juveniles of the common goby (Pomatoschistus microps): Confusion with prey, reduction of the predatory performance and efficiency, and possible influence of developmental conditions. Environ. Pollut. 2015, 196, 359-362. [CrossRef] [PubMed]

107. Gambardella, C.; Piazza, V.; Albentosa, M.; Bebianno, M.J.; Cardoso, C.; Faimali, M.; Garaventa, F.; Garrido, S.; González, S.; Pérez, S.; et al. Microplastics do not affect standard ecotoxicological endpoints in marine unicellular organisms. Mar. Pollut. Bull. 2019, 143, 140-143. [CrossRef] [PubMed]

108. Frydkjær, C.K.; Iversen, N.; Roslev, P. Ingestion and Egestion of Microplastics by the Cladoceran Daphnia magna: Effects of Regular and Irregular Shaped Plastic and Sorbed Phenanthrene. Bull. Environ. Contam. Toxicol. 2017, 99, 655-661. [CrossRef] [PubMed]

109. Lusher, A.; McHugh, M.; Thompson, R.C. Occurrence of microplastics in the gastrointestinal tract of pelagic and demersal fish from the English Channel. Mar. Pollut. Bull. 2013, 67, 94-99. [CrossRef] [PubMed]

110. Mazurais, D.; Ernande, B.; Quazuguel, P.; Severe, A.; Huelvan, C.; Madec, L.; Mouchel, O.; Soudant, P.; Robbens, J.; Huvet, A.; et al. Evaluation of the impact of polyethylene microbeads ingestion in European sea bass (Dicentrarchus labrax) larvae. Mar. Environ. Res. 2015, 112, 78-85. [CrossRef] [PubMed]

111. Sigurnjak, M.; Ukić, Š.; Cvetnić, M.; Markić, M.; Novak Stankov, M.; Rasulev, B.; Kušić, H.; Lončarić Božić, A.; Rogošić, M.; Bolanča, T. Combined toxicities of binary mixtures of alachlor, chlorfenvinphos, diuron and isoproturon. Chemosphere 2020, 240, 124973. [CrossRef]

112. Gagné, F. Toxicity and disruption of quorum sensing in Aliivibrio fisheri by environmental chemicals: Impacts of selected contami-nants and microplastics. J. Xenobiot. 2017, 7, 15-20. [CrossRef]

113. Casado, M.P.; Macken, A.; Byrne, H.J. Ecotoxicological assessment of silica and polystyrene nanoparticles assessed by a multitrophic test battery. Environ. Int. 2013, 51, 97-105. [CrossRef]

114. Bhattacharya, P.; Lin, S.; Turner, J.P.; Ke, P.C. Physical Adsorption of Charged Plastic Nanoparticles Affects Algal Photosynthesis. J. Phys. Chem. C 2010, 114, 16556-16561. [CrossRef]

115. Mao, Y.; Ai, H.; Chen, Y.; Zhang, Z.; Zeng, P.; Kang, L.; Li, W.; Gu, W.; He, Q.; Li, H. Phytoplankton response to polystyrene mi-croplastics: Perspective from an entire growth period. Chemosphere 2018, 208, 1-40. [CrossRef] [PubMed]

116. Wu, Y.; Guo, P.; Zhang, X.; Zhang, Y.; Xie, S.; Deng, J. Effect of microplastics exposure on the photosynthesis system of freshwater algae. J. Hazard. Mater. 2019, 374, 219-227. [CrossRef] [PubMed]

117. Lagarde, F.; Olivier, O.; Zanella, M.; Daniel, P.; Hiard, S.; Caruso, A. Microplastic interactions with freshwater microalgae: Het-ero-aggregation and changes in plastic density appear strongly dependent on polymer type. Environ. Pollut. 2016, 215, 331-339. [CrossRef] [PubMed]

118. Zhang, P.; Yan, Z.; Lu, G.; Ji, Y. Single and combined effects of microplastics and roxithromycin on Daphnia magna. Environ. Sci. Pollut. Res. 2019, 26, 17010-17020. [CrossRef]

119. Rehse, S.; Kloas, W.; Zarfl, C. Short-term exposure with high concentrations of pristine microplastic particles leads to immobilisation of Daphnia magna. Chemosphere 2016, 153, 91-99. [CrossRef]

120. Jaikumar, G.; Baas, J.; Brun, N.R.; Vijver, M.G.; Bosker, T. Acute sensitivity of three Cladoceran species to different types of mi-croplastics in combination with thermal stress. Environ. Pollut. 2018, 239, 733-740. [CrossRef]

121. Kokalj, A.J.; Horvat, P.; Kunej, U.; Bele, M.; Kržan, A. Uptake and effects of microplastic textile fibers on freshwater crustacean Daphnia magna. Environ. Pollut. 2016, 219, 201-209. [CrossRef]

122. Jemec Kokalj, A.; Kuehnel DPuntar, B.; Žgajnar Gotvajn, A.; Kalčikova, G. An exploratory ecotoxicity study of primary microplastics versus aged in natural waters and wastewaters. Environ. Pollut. 2019, 254, 112980. [CrossRef]

123. Lei, L.; Wu, S.; Lu, S.; Liu, M.; Song, Y.; Fu, Z.; Shi, H.; Raley-Susman, K.M.; He, D. Microplastic particles cause intestinal damage and other adverse effects in zebrafish Danio rerio and nematode Caenorhabditis elegans. Sci. Total Environ. 2018, 1-8. [CrossRef]

124. Chen, Q.; Gundlach, M.; Yang, S.; Jiang, J.; Velki, M.; Yin, D.; Hollert, H. Quantitative investigation of the mechanisms of micro-plastics and nanoplastics toward zebrafish larvae locomotor activity. Sci. Total Environ. 2017, 584, 1022-1031. [CrossRef]

125. Lu, Y.; Zhang, Y.; Deng, Y.; Jiang, W.; Zhao, Y.; Geng, J.; Ding, L.; Ren, H.-Q. Uptake and Accumulation of Polystyrene Microplastics in Zebrafish (Danio rerio) and Toxic Effects in Liver. Environ. Sci. Technol. 2016, 50, 4054-4060. [CrossRef] [PubMed]

126. Jabeen, K.; Su, L.; Li, J.; Yang, D.; Tong, C.; Mu, J.; Shi, H. Microplastics and mesoplastics in fish from coastal and fresh waters of China. Environ. Pollut. 2017, 221, 141-149. [CrossRef] [PubMed]

127. Pegado, T.S.S.; Schmid, K.; Winemiller, K.O.; Chelazzi, D.; Cincinelli, A.; Dei, L.; Giarrizzo, T. First evidence of microplastic inges-tion by fishes from the Amazon River estuary. Mar. Pollut. Bull. 2018, 133, 814-821. [CrossRef] [PubMed]

128. Abbas, M.; Adil, M.; Ehtisham-Ul-Haque, S.; Munir, B.; Yameen, M.; Ghaffar, A.; Shar, G.A.; Tahir, M.A.; Iqbal, M. Vibrio fischeri bioluminescence inhibition assay for ecotoxicity assessment: A review. Sci. Total Environ. 2018, 626, 1295-1309. [CrossRef] [PubMed]

129. Leroueil, P.R.; Berry, S.A.; Duthie, K.; Han, G.; Rotello, V.M.; McNerny, D.Q.; Baker, J.R.; Orr, B.G.; Banaszak Holl, M.M. Wide varieties of cationic nanoparticles induce defects in supported lipid bilayersnls. Nano Lett. 2008, 8, 420-424. [CrossRef]

130. Canniff, P.M.; Hoang, T.C. Microplastic ingestion by Daphnia magna and its enhancement on algal growth. Sci. Total Environ. 2018, 633, 500-507. [CrossRef] 
131. Ma, Y.; Huang, A.; Cao, S.; Sun, F.; Wang, L.; Guo, H.; Ji, R. Effects of nanoplastics and microplastics on toxicity, bioaccumulation, and environmental fate of phenanthrene in fresh water. Environ. Pollut. 2016, 219, 166-173. [CrossRef]

132. Ogonowski, M.; Schür, C.; Jarsén, Å.; Gorokhova, E. The Effects of Natural and Anthropogenic Microparticles on Individual Fitness in Daphnia magna. PLoS ONE 2016, 11, e0155063. [CrossRef]

133. Besseling, E.; Wang, B.; Lürling, M.; Koelmans, A.A. Nanoplastic Affects Growth of S. obliquus and Reproduction of D. magna Environ. Sci. Technol. 2014, 48, 12336-12343. [CrossRef]

134. Sanchez, W.; Bender, C.; Porcher, J.M. Wild gudgeons (Gobio gobio) from French rivers are contaminated by microplastics: Pre-liminary study and first evidence. Environ. Res. 2014, 128, 98-100. [CrossRef]

135. Campbell, S.H.; Williamson, P.R.; Hall, B.D. Microplastics in the gastrointestinal tracts of fish and the water from an urban prairie creek. Facet 2017, 2, 395-409. [CrossRef]

136. Ramos, J.; Barletta, M.; Costa, M. Ingestion of nylon threads by Gerreidae while using a tropical estuary as foraging grounds. Aquat. Biol. 2012, 17, 29-34. [CrossRef]

137. Oliveira, M.C.L.; Ribeiro, A.L.P.; Hylland, K.; Guilhermino, L. Single and combined effects of microplastics and pyrene on juveniles (0+ group) of the common goby Pomatoschistus microps (Teleostei, Gobiidae). Ecol. Indic. 2013, 34, 641-647. [CrossRef]

138. Lönnstedt, O.M.; Eklöv, P. Environmentally relevant concentrations of microplastic particles influence larval fish ecology. Science 2016, 352, 1213-1216. [CrossRef]

139. Rochman, C.M.; Hoh, E.; Kurobe, T.; Teh, S.J. Ingested plastic transfers hazardous chemicals to fish and induces hepatic stress. Sci. Rep. 2013, 3, 3263. [CrossRef]

140. Saley, A.; Smart, A.; Bezerra, M.; Burnham, T.; Capece, L.; Lima, L.; Carsh, A.; Williams, S.; Morgan, S. Microplastic accumulation and biomagnification in a coastal marine reserve situated in a sparsely populated area. Mar. Pollut. Bull. 2019, 146, 54-59. [CrossRef]

141. Pazos, R.S.; Maiztegui, T.; Colautti, D.C.; Paracampo, A.H.; Gómez, N. Microplastics in gut contents of coastal freshwater fish from Río de la Plata estuary. Mar. Pollut. Bull. 2017, 122, 85-90. [CrossRef]

142. Veneman, W.J.; Spaink, H.P.; Brun, N.R.; Bosker, T.; Vijver, M.G. Pathway analysis of systemic transcriptome responses to injected polystyrene particles in zebrafish larvae. Aquat. Toxicol. 2017, 190, 112-120. [CrossRef]

143. Bhagat, J.; Zang, L.; Nishimura, N.; Shimada, Y. Zebrafish: An emerging model to study microplastic and nanoplastic toxicity. Sci. Total Environ. 2020, 728, 138707. [CrossRef]

144. Zhao, Y.; Bao, Z.; Wan, Z.; Fu, Z.; Jin, Y. Polystyrene microplastic exposure disturbs hepatic glycolipid metabolism at the physio-logical, biochemical, and transcriptomic levels in adult zebrafish. Sci. Total Environ. 2019, 710, 1-34.

145. Lee, W.S.; Cho, H.J.; Kim, E.; Huh, Y.H.; Kim, H.J.; Kim, B.; Kang, T.; Lee, J.S.; Jeong, J. Bioaccumulation of polystyrene nano-plastics and their effect on the toxicity of Au ions in zebrafish embryos. Nanoscale 2019. [CrossRef]

146. Parenti, C.C.; Ghilardi, A.; Della Torre, C.; Magni, S.; Del Giacco, L.; Binelli, A. Evaluation of the infiltration of polystyrene nano-beads in zebrafish embryo tissues after short-term exposure and the related biochemical and behavioural effects. Environ. Pollut. 2019, 254, 112947. [CrossRef] [PubMed]

147. Fang, S.; Yu, W.; Li, C.; Liu, Y.; Qiu, J.; Kong, F. Adsorption behavior of three triazole fungicides on polystyrene microplastics. Sci. Total Environ. 2019, 691, 1119-1126. [CrossRef] [PubMed]

148. Prata, J.C.; Lavorante, B.R.B.O.; Montenegrod, B.S.M.; Guilhermino, L. Influence of microplastics on the toxicity of the pharmaceuticals procainamide and doxycycline on the marine microalgae Tetraselmis chuii. Aquat. Toxicol. 2018, 197, 143-152. [CrossRef]

149. Bayo, J.; Olmos, S.; López-Castellanos, J.; Alcolea, A.; Brebbia, C.A.; Itoh, H. Microplastics and microfibers in the sludge of a municipal wastewater treatment plant. Int. J. Sustain. Dev. Plan. 2016, 11, 812-821. [CrossRef]

150. Alimi, O.S.; Budarz, J.F.; Hernandez, L.M.; Tufenkji, N. Microplastics and Nanoplastics in Aquatic Environments: Aggregation, Deposition, and Enhanced Contaminant Transport. Environ. Sci. Technol. 2018, 52, 1704-1724. [CrossRef]

151. Zhang, Q.; Qu, Q.; Lu, T.; Ke, M.; Zhu, Y.; Zhang, M.; Zhang, Z.; Du, B.; Pan, X.; Sun, L.; et al. The combined toxicity effect of nanoplastics and glyphosate on Microcystis aeruginosa growth. Environ. Pollut. 2018, 243, 1106-1112. [CrossRef]

152. Sleight, V.A.; Bakir, A.; Thompson, R.C.; Henry, T.B. Assessment of microplastic-sorbed contaminant bioavailability through analysis of biomarker gene expression in larval zebrafish. Mar. Pollut. Bull. 2017, 116, 291-297. [CrossRef]

153. Lu, K.; Qiao, R.; An, H.; Zhang, Y. Influence of microplastics on the accumulation and chronic toxic effects of cadmium in zebrafish (Danio rerio). Chemosphere 2018, 202, 514-520. [CrossRef]

154. Luís, L.G.; Ferreira, P.; Fonte, E.; Oliveira, M.; Guilhermino, L. Does the presence of microplastics influence the acute toxicity of chromium(VI) to early juveniles of the common goby (Pomatoschistus microps)? A study with juveniles from two wild estuarine populations. Aquat. Toxicol. 2015, 164, 163-174. [CrossRef]

155. Besseling, E.; Wegner, A.; Foekema, E.M.; Heuvel-Greve, M.J.V.D.; Koelmans, A.A. Effects of Microplastic on Fitness and PCB Bioaccumulation by the Lugworm Arenicola marina (L.). Environ. Sci. Technol. 2013, 47, 593-600. [CrossRef] [PubMed]

156. Devriese, L.I.; De Witte, B.; Vethaak, A.D.; Hostens, K.; Leslie, H. Bioaccumulation of PCBs from microplastics in Norway lobster (Nephrops norvegicus): An experimental study. Chemosphere 2017, 186, 10-16. [CrossRef] [PubMed]

157. Horton, A.A.; Vijver, M.G.; Lahive, E.; Spurgeon, D.J.; Svendsen, C.; Heutink, R.; Van Bodegom, P.M.; Baas, J. Acute toxicity of organic pesticides to Daphnia magna is unchanged by co-exposure to polystyrene microplastics. Ecotoxicol. Environ. Saf. 2018, 166, 26-34. [CrossRef] [PubMed] 
158. EU. Directive 2013/39/EU of the European Parliament and of the Council amending Directives 2000/60/EC and 2008/105/EC as regards priority substances in the field of water policy. Off. J. Eur. Commun. 2013, 226, 1-17.

159. JCR. Technical Report: Review of the 1st Watch List under the Water Framework Directive and recommendations for the 2nd Watch List. 2018. Available online: https://publications.jrc.ec.europa.eu/repository/bitstream/JRC111198/wl_report_jrc_2018_0 4_26_final_online.pdf (accessed on 23 October 2020).

160. Alavanja, M.C.R. Pesticides use and exposure extensive worldwide. Rev. Environ. Health 2009, 24, 303-309. [CrossRef]

161. Astner, A.; Hayes, D.G.; O’Neill, H.; Evans, B.; Pingali, S.; Urban, V.; Young, T. Mechanical formation of micro- and nano-plastic materials for environmental studies in agricultural ecosystems. Sci. Total Environ. 2019, 685, 1097-1106. [CrossRef] 